\title{
Okul Öncesi Dönem Çocuklarının Doğaya Yakınlık (Biyofili) Seviyelerinin Araştırılması*
}

\author{
An Investigation of Preschool Children's Affinity Towards \\ Nature (Biophilia)
}

\author{
Simge YILMAZ**, Refika OLGAN***
}

\begin{abstract}
Öz: Bu çalışmanın amacı okul öncesi eğitim kurumlarına devam eden 60-66 aylık çocuklarının doğaya yakınlık seviyelerini (biyofili) belirlemek ve bu çocukların doğa ile ilgili uyaranlara olumlu (biyofilik) ya da olumsuz (biyofobik) tepkilerinin nedenlerini araştırmaktır. Bu çalışmanın bir diğer amacı ise çocukların biyofili seviyelerinin devam ettikleri okul öncesi eğitim kurumlarının bahçelerinin doğal elementleri içerme düzeylerine ve cinsiyetlerine göre değişiklik gösterip göstermediğini araştırmaktır. Çalışmanın örneklemi Ankara İl'inin Çankaya ilçesinde yer alan dört farklı devlet okulundan seçilen 105 çocuktan oluşmuştur. Çalışmanın alt örneklemini ise temel örneklem grubundan rastgele örnekleme yöntemi kullanılarak seçilen 20 çocuk oluşturmaktadır. Katılımcıların doğaya yakınlık seviyelerini ölçmek amacıyla 22 maddeden oluşan 'Çocuklar için Biyofili Ölçeği' kullanılmıştır. Çalışmanın bulguları, çocukların biyofili seviyelerinin devam ettikleri okul öncesi eğitim kurumuna (okul öncesi eğitim kurumlarının bahçelerinin doğal elementleri içerme düzeyleri) ve cinsiyetlerine göre farklılık göstermediğini ve araştırmaya katılan tüm çocukların biyofili seviyelerinin yüksek olduğunu göstermiştir. Çocukların biyofilik ya da biyofobik yanıtlarının ortak nedenleri incelendiğinde, öne çıkan en önemli faktörün kültürün etkisi olduğu belirlenmiştir. Annelerin çocukların doğal uyaranlara verdiği olumlu ya da olumsuz tepkiler üzerinde etkili bir yere sahip olduğu belirlenmiştir. Bu nedenle, ilerde yapılacak çalışmaların çocukların biyofilik ya da biyofobik yanıtlarında etkili olabileceği düşünülerek, annelerin demografik özellikleri (yaş, eğitim seviyesi, dışarda geçirdiği zaman, çocukluğunu geçirtiği yaşam alanı vb.) dikkate alınarak planlanması önerilebilir. Ayrıca, farklı kültürlerde büyüyen çocukların biyofili seviyelerinin araştırılması da önerilebilir.
\end{abstract}

Anahtar Kelimeler: Biyofili, biyofobi, doğaya yakınlık, okul öncesi eğitim

\begin{abstract}
The current research aims to investigate 60-66 months-old preschool children's affinity towards nature (biophilia) and to identify the reasons of their positive (biophilic) and negative (biophobic) reactions to a natural stimulus. This research also aims to explore if preschool children's levels of biophilia differ depending on two factors: the levels of naturalness of the outdoor environments of the early child care centers that children enrolled and the gender. The sample of the study consisted of 105 children selected from four public preschools located in the same district of Ankara. The sub-sample included 20 children who were randomly selected from the main sample. 'Children's Biophilia Measure', which has 22 items, was used to explore the participants' levels of affinity towards nature. According to the results, children's levels of biophilia was pretty high and did not differ based on their school type (the level of naturalness of the school garden) and gender. It was found that the culture was the prominent factor affecting the reasons of the children's biophilic and biophobic responses. In particular, mothers had an important impact on their children's positive or negative responses to a natural stimulus. Therefore, further research is suggested to be planned considering the possible effect of mothers' demographic information (age, educational level, time spent outdoors, living environment where mothers spent their childhood etc.) on children's biophilic or biophobic preferences. As a further research, it is also suggested to investigate biophilia of children who are coming from different cultures.
\end{abstract}

Keywords: Biophilia, biophobia, affinity towards nature, early childhood education

\footnotetext{
*Bu çalışma birinci yazarın tez çalışmasının bir kısmından oluşturulmuştur.

**Arş. Gör. Dr., Mersin Üniversitesi, Eğitim Fakültesi, Mersin-Türkiye, e-posta: simgeyilmaz@mersin.edu.tr

***Doç. Dr. Refika Olgan, Orta Doğu Teknik Üniversitesi, Eğitim Fakültesi, Ankara-Türkiye, eposta: rolgan@metu.edu.tr
} 


\section{Giriş}

\section{Okul Öncesi Eğitim Dönemindeki Çocukların Doğaya Yakınlığı (Biyofili)}

Biyofili, yaşam ile bağlantı kurmak ve sürdürmek amacıyla ortaya çıan genetik temelli insan ihtiyacı ve eğilimi olarak tanımlanabilir (Kahn, 1997). Yapılan araştırmalar bireylerin hayvan, bitki, bitki örtüsü, su, hayvan sesleri/hareketleri ve mevsimsel değişiklikler gibi doğal uyaranlara doğuştan gelen bir yakın olma isteği olduğunu göstermektedir (Dubos, 1968; Iltis, Loucks, ve Andrews, 1970; Kahn, 1997). Bazı araştırmalarda ise (Örn: Tilbury, 1994; Kellert, 2005), biyofili doğuştan gelen doğal çevreyi araştırma eğilimi olarak tanımlanmaktadır. Mevcut çalışma kapsamında ise biyofili Wilson'un (1993) tanımlaması dikkate alınarak bireylerin genetik olarak doğaya yakın olma durumu ve doğaya karşı olumlu tepkileri olarak tanımlanmaktadır.

Birçok teori (örn: Evrimsel teori, biyofili teorisi ve ekolojik teori) insanoğlunun herhangi bir doğal uyarana yakın olma eğiliminin amacını açıklamayı amaçlamıştır (Appleton, 1975, 1996; Coss ve Charles, 2004; Orians, 1986; Wilson, 1984). Bu doğrultuda baz1 araştırmacılar insanlığın evrimsel temellerinin kişisel açık alan tercihleri üzerinde etkili olduğunu belirtmiştir (Appleton, 1975; Coss ve Charles, 2004; Orians, 1986; Wilson, 1984). Evrimsel bakış açısı insanoğlunun özellikle çalılıkların ve aralıklı ağaç topluluklarının bulunduğu geniş çayırları tercih etmeye doğuştan eğilimli olduğunu vurgulamaktadır (Appleton, 1975). Falk'ta (1977) insanlığın Doğu Afrika çayırlarında hayatta kalabilmek için geçirmiş olduğu evrimsel adaptasyonun, bireylerin açık alan tercihleri üzerinde etkili olduğunu ifade eder. Wilson $(1984,1993)$ ve Kellert ve Wilson (1995) ise, insanların yaşam alanı olarak belirledikleri uygun ve verimli çevreleri içgüdüsel olarak seçtiklerini belirtir. İnsanların su bulunan alanları tercih etme eğilimlerinin, suyun yaşamı sürdürmek için en temel ihtiyaçlardan biri olması ile ilişkilendirilmesi de evrimsel bakıș açısı ile açıklanabilir.

Evrimsel bakış açısı, insanoğlunun doğayı ve canlıları araştırmaya doğuştan eğilimli olduğunu açıklarken, bireylerin bazı durumlarda doğal uyaranlardan ya da doğal çevreden kaçındığına da vurgu yapmaktadır (Kahn, 1997; Kellert, 2012; Wilson, 1984). Kellert ve Wilson (1995), bireylerin kendilerine avantaj sağlayacak ya da onlar için tehlike arz edebilecek durumlara karşı, doğuştan getirdikleri olumlu ya da olumsuz tepkilerinin (biyofili/biyofobi) varlığından söz eder. Bu araştırmacılar, bahsi geçen avantajların yiyecek, su ve güvenlik gibi insanların hayatta kalmalarını sağlayacak ihtiyaçlarla ilişkili olabildiğini, tehlike arz edebilecek durumların ise yılan, örümcek gibi yaşamı tehdit edebilecek riskli doğal uyaranlar veya yükseklik ve karanlık gibi bireylerde korku uyandırabilecek durumlar olduğunu belirtmiştir (Wilson ve Kellert, 1995). Bu bilgiler, çocuklarda biyofili ya da biyofobi gelişiminin çok küçük yaşlardan itibaren evrimsel yaklaşım ile açıklanabilirliğini doğrulamaktadır (Wilson, 1984). Bu noktada, küçük çocuklarda biyofili ve biyofobi seviyelerini anlamanın önemi ortaya çıkmaktadır.

Küçük çocuklarda biyofili gelişimi incelendiğinde, bu gelişimin yaşamın ilk yıllarından itibaren şekillenmeye başladığı belirtilmektedir (Moore ve Marcus, 2008). Çocuklar doğal çevreyi keşfetmeye ihtiyaç duyarlar ve bu gibi ortamlarda öğrenmenin gerçekleşmesi için kendi inisiyatiflerini kullanırlar (Thompson ve Thompson, 2007). Rivkin (1995), çocukların bu yöndeki davranışlarının temelinde, doğanın çocuklara sunmuş olduğu rahatlık ve özgürlük hissi ve onlara kendi oyunlarını kurma imkânı veren çeşitli kaynaklar sunması ile ilişkili olabileceğini savunur. Benzer şekilde Chawla (2007) da, doğanın sahip olduğu materyallerin ve elementlerin çocukların dikkatini çektiğini ve onlarda sürekli olarak evredeki uyaranlarla etkileşimde olma isteği uyandırdığını belirtmektedir.

Öte yandan küçük çocuklarda biyofobi gelişimi, genetik olarak doğuştan getirdiğimiz bir olgudan ziyade, doğal uyaranlara karşı kültürün etkisi ile dolaylı olarak kazanılabilen ya da öğrenilebilen tepkiler olarak karşımıza çıkar (Ulrich, 1993). Daha farklı bir ifadeyle, biyofobi bireylerde korku ve sakınma duygusu oluşturabilecek yılan, sıçan ve örümcek gibi uyaranlara karş1 olumsuz ve öğrenilmiş tepkileridir (Ulrich, 1993). Hayvanlar ve insanlarla yapılan deneysel çalışmalar biyofobi ile ilgili belirtilen bu ifadeleri doğrulamaktadır. Örneğin, birçok araştırmacı maymunların oyuncak yılanlara olan tepkilerinin korku ile ilişkili tepkiler 
olduğunu belirtirken, aynı hayvanların oyuncak tavşanlara tam tersine olumlu tepkiler verdiklerini gözlemlemiştir (Cook ve Mineka, 1989; 1990; Mineka, Cook ve Keir, 1984). Öte yandan, insanlarla yapılan çalışmalar bireylerin doğal uyaranlara vermiş oldukları korku dolu tepkilerin, başka bireylerin benzer bir doğal uyarana göstermiş oldukları acı ile sonuçlanan tepkilerini gözlemleyerek kazandıklarını ortaya çıkarmıştır (Ulrich, 1993).

$\mathrm{Bu}$ bilgiler 1şığında çocuklara doğa sevgisi aşılamak, onların doğayla etkileşimlerini ve doğaya yakınlıklarını artırmak ya da çocukları doğa ile ilişkili herhangi bir uyarana karşı verilebilecekleri olumsuz tepkilerden ve korkulardan korumak için, onlara doğada keşif yapma ve farklı deneyimler kazanma firsatlarının sunulması önemlidir (Chawla, 2006; Sobel, 2008). Bununla birlikte, çocukların doğaya karşı olumlu tutumları, değerleri ve temel eğilimleri erken çocukluk döneminde şekillendiğinden, onlara yaşamlarının ilk yıllarından itibaren her canlının, hatta kendilerinin de doğanın bir parçası olduğu bilincinin aşılanması önemlidir (Kahn, 2002; Kellert, 1997).

Ancak günümüzde çocuklara doğada özgür bir şekilde keşif yapma imkânı çeşitli faktörlerin etkisi ile sınırlandırılmaktadır (Louv, 2005). İnsanların hüküm sürdügü̈, doğal yapısı bozulmuş alanlar, çocukların doğadan uzaklaşmasında etkin olan en önemli faktörlerin başında gelmektedir (Turner, Nakamura ve Dinetti, 2004). Uzun süre televizyon ya da bilgisayar karşısında hareketsiz zaman geçirmeleri de çocukların açık alanlarda zaman geçirmelerinin önündeki en büyük engellerden bir diğeridir (Clements, 2004). Rosenow (2008) bu durumu "küçük çocuklar kablosuz ağa bağlı Blackberry'lere (telefon markası) doğada yetişen blackberrylerden (böğürtlen meyvesi) çok daha aşina olarak büyümektedir" (s. 11) şeklinde yorumlamaktadır. Louv da (2005), günümüz çocuklarının açık alanlarda vakit geçirme firsatlarının sınırlı olduğunu, bu alanlarda vakit geçirme firsatını elde etseler bile, bu alanların doğallık bakımından yetersiz olduğuna dikkat çekmiştir. Diğer bir taraftan, bazı araştırmacılar ise çocukların doğadan kopuk yetişmesinde algılanan tehlikelerin ve kültürün önemini vurgular (Bekoff ve Goodall, 2007; Louv, 2005). Louv (2008), bahsedilen bu faktörlerin olumsuz etkilerinin ortaya çıkarabileceği 'doğa yoksunluğu sendromu'ndan bahseder. Birçok araştırmacıya göre, bireylerin doğa ile bağının azalması ya da tamamen kopması, onların yaşamları boyunca doğayı korumak ve doğaya saygılı davranmak konularında özensiz olabileceklerine işaret etmektedir (Chawla 1999; 2007; Engleson ve Yockers, 1994; Samways, 2007; Wells ve Lekies, 2006). Özetle, hem insanların hem de doğanın sağlıklı olabilmesi büyük ölçüde birbirleri ile ilişkilidir (Kellert, 1993; Wilson, 1993). Birçok araştırmacıya göre, doğadan kopuk bir şekilde büyümek, çocuklarda bir yandan biyofilinin gelişimi için bir engel olarak düşünülürken (Stokes, 2006), diğer yandan da biyofobinin gelişimine zemin hazırlayabilir (Orr, 1994; Simaika ve Samways, 2010; White, 2004; White ve Stoecklin, 1998). Kısaca, erken çocukluk yıllarında edindiğimiz davranışsal eğilimler ya doğaya yakınlığımızı korumamızı teşvik eder ya da çevreye zarar verebilecek davranışları benimsememize neden olabilir (Gardner ve Stern, 2002).

\section{Çocukların Biyofilisinin Araştırılmasının Önemi}

İlgili alan yazında yetişkinlerin doğaya yakınlığını araştıran çok sayıda çalışma bulunmasına rağmen (Mayer ve Frantz, 2004; Nisbet, Zelensky ve Murphy, 2009), çocukların doğaya yakınlığı, diğer bir deyişle çocukların biyofili seviyeleri, son yıllara kadar çok fazla araştırılan bir konu olmamıştır (Rice ve Torquati, 2013). Çocukların biyofili seviyesini ölçen ilk ölçme aracı 2013 yılında Rice ve Torquati tarafindan geliştirilen biyofili ölçeği olmuştur. Rice ve Torquati (2013), özellikle annelerin eğitim seviyesi, aile gelir düzeyi ve çocukların devam ettikleri okulların oyun alanları ve okul bahçelerinin doğal elementleri içerme oranı gibi çeşitli etmenler ile çocukların biyofili seviyeleri arasındaki ilişkiyi belirlemeye yönelik araştırmalar yürütmüşlerdir. Ayrıca araştırmacılar, kendi araştırma bulguları doğrultusunda gelecekte bu konu ile ilgili araştırma yapmayı planlayan araştırmacılara yön göstererek ebeveynler vasıtası ile çocuklarda biyofilinin gelişimine etki edebilecek daha farklı etmenlerin (örn: okul bahçesi dışında doğal açık alanlarda geçirilen zaman, ulaşılabilir doğal açık alanların kullanımı, çocukların zaman geçirdiği doğal alanların özellikleri, doğal açık alanların çocukların 
yaşadıkları alanlara yakınlığı gibi) araştırılmasının önemli olduğunu ve bu nedenle gelecekte araştırmaların bu yönde planlanabileceğini belirtmişlerdir.

İlgili alan yazın incelendiğinde, özellikle okul öncesi dönemdeki çocuklarla yapılan çalışmaların kısıtlı olduğu tespit edilmiş olup, mevcut araştırma okul öncesi eğitime devam eden çocukların doğaya yakınlık seviyelerinin belirlenmesi ve doğa ile ilgili uyaranlara karşı olumlu ya da olumsuz tepkilerinin detaylı incelenmesi bakımından önem taşımaktadır. Ayrıca, çocukların biyofili seviyelerinin araştırılması, onların doğaya ne ölçüde yakın ya da doğadan ne ölçüde kopuk olduklarını anlamamıza yardımcı olacak ve ilgili planlamalara yön gösterecektir. Ayrıca, çocukların doğa ile ilgili uyaranlara biyofilik ya da biyofobik tepkileri, onların yaşamları boyunca doğaya duyabilecekleri saygı ve doğayı koruma biçimleri gibi konularda da fikir verebilir (Schultz, 2000). Benzer bir şekilde, Nisbet ve diğerleri de (2009), çocukların doğaya yakınlık seviyelerinin bilinmesinin, onların yaşamları boyunca doğaya karşı sorumluluk sahibi olma potansiyelleri konusunda bilgi verebileceğini vurgular. Bu doğrultuda, mevcut çalışma özellikle okul öncesi eğitim alanında bu konu ile ilgili araştırmaların yetersizliği dikkate alarak planlanmış ve aşağıda sunulan araştırma sorularını cevaplamayı amaçlamıştır:

1. 60-66 aylık çocukların biyofili seviyeleri nedir?

1.a. 60-66 aylık çocukların biyofili seviyeleri devam ettikleri okul öncesi eğitim

kurumlarının bahçelerinin doğal elementleri içerme düzeylerine göre farklılık göstermekte midir?

1b. 60-66 aylık çocukların biyofili seviyeleri cinsiyetlerine göre farklılık göstermekte midir?

2. 60-66 aylık çocukların doğa ile ilişkili uyaranlara karşs olumlu ya da olumsuz tepkilerinin nedenleri nelerdir?

\section{Yöntem}

\section{Çalışmanın Deseni}

$\mathrm{Bu}$ çalışmada nicel ve nitel araştırma yöntemleri birlikte kullanılmıştır. Okul öncesi eğitim kurumlarına devam eden 60-66 aylık çocuklarının biyofili seviyeleri (doğaya yakınlık seviyesi) nicel araştırma yöntemleri kullanılarak araştırılmıştır. Örneklem grubundaki çocukların biyofilisi 'Çocuklar için Biyofili Ölçeği' kullanılarak araştırılmıştır. Örneklem grubundan seçilen 20 çocuğun, biyofili ölçeğindeki maddelere verdikleri yanıtların nedenleri ise nitel araştırma yöntemleri ile araştırılmıştır. Creswell (1999) nicel ve nitel araştırma yöntemlerini birlikte kullanmanın bir araştırma probleminin sonuçlarını ortaya çıkarmada ve yorumlamada önemli ve anlamlı olduğunu ifade etmektedir.

\section{Ortamlar}

Çalışmanın örneklemi Ankara İl'inin Çankaya ilçesinde yer alan dört farklı devlet okulundan seçilmiştir. Okullar belirlenirken, kurumların bahçelerindeki çim, ağaç, çalı, çiçek gibi doğal elementlerin bulunma oranına bağlı olarak, okullardan ikisi doğal okullar, diğer ikisi ise doğal olmayan okullar şeklinde kodlanmıştır. Doğal okul kapsamında yer alan okulları, okul bahçeleri itibarıla doğal okul kapsamında olmayan okullarından farklı olarak çocuklara yukarında bahsedilen doğal elementlerle etkileşim kurabilecekleri geniş bir açık alan sunmaktadır. Doğal okul kapsamında olan okullarında çocuklar uygulanan eğitim programı dâhilinde düzenli olarak her gün sınıf dışında en az iki saat geçirmektedir. Doğal okul kapsamında olmayan okullarında ise çocukların sınıf dışında zaman geçirme süresi haftada ya da iki haftada bir olmaktadır. Aşağıda doğal olan ve doğal olmayan dört farklı okulun, okul bahçeleri ile ilgili ayrıntılı bilgi verilmiştir.

\section{Doğal Olan ve Doğal Olmayan Okul Ortamlarının Özellikleri}

İlk doğal anaokulunun tüm sınıflarını birbirine bağlayan, çocuklarının aktif olarak kullanabildiği geniş bir bahçe ile çevrili tek katlı büyük bir binası vardır. Okul bahçesinin 
etrafı çitlerle çevrilidir. Okul binasının etrafında üç yönlü açık alan bulunmaktadır. Birinci kısım, kenarında çalılar ve ağaçlar bulunduran hoş bir tuğla yol ve okulun giriş kapısını içerir. Girişin sağ tarafinda da okul bahçesinin bir ucundan diğerine uzanan, kenarları ağaçlarla kaplı bir yol bulunmaktadır. Bu kısımdan, tırmanma oyuncakları, salıncaklar ve tahterevallilerin bulunduğu ikinci bölüme de geçiş bulunmaktadır. Ayrıca, ana oyun alanına bitişik olan ve tırmanma çubukları ve plastik bir tırmanma ve kayma kalesi bulunduran daha küçük bir oyun alanı bulunmaktadır. Bu oyun bahçesi, kum ve çim de dâhil olmak üzere geniş bir zemine sahiptir. Girişin sol tarafında ise, uzun ağaçların gölge oluştuğu bir alan bulunmaktadır. $\mathrm{Bu}$ alanda ayrıca çocuklar için küçük bir kaydırak ve yemek yemek için ya da çocukların masa etkinliklerini yapabilmeleri için kullanacak piknik masaları bulunmaktadır. Bu alan aynı zamanda çocukların aktif hareket edebileceği kadar geniştir. Okul binasın bahçe ile birleştiği bölümde gölgelikle kaplanmış geniş bir alan bulunmaktadır. $\mathrm{Bu}$ alanda, çocukların kullanabileceği arabalar, oyun evleri, sallanan oyuncaklar, küçük salıncaklar ve piknik masaları gibi birçok oyun malzemesi bulunmaktadır. Ayrıca, bu alan araba ve bisiklet sürmeyi kolaylaştıran tuğlalardan yapılmış zemine sahiptir.

İkinci doğal anaokulu, etrafı çitle çevrilmiş geniş bir çim alana sahip tek katlı büyük bir binadır. Okulun girişinde, her iki tarafında renkli saksıların bulunduğu, uzun asfalt bir yürüyüş yolu bulunmaktadır. Bu bölümün sağ tarafinda hayvan heykelleri, sanat heykelleri, çok sayıda ağaç ve büyük bitkiler bulunduran yemyeşil çimlerin yer aldığı bir bölüm bulunmaktadır. Bu bölümün sol tarafında ise, Atatürk büstü, birkaç hayvan heykeli, ağaçlar ve çiçekler bulunmaktadır. Okul binasının sol tarafında hayvan figürlü kumaşlarla kaplı ağaçlar, çiçek saksıları yapmak için bir araya getirilen renkli boyalarla boyanmış kamyon lastikleri, bir oyun evi, rüzgâr çanı görevi gören ağaçlara asılı kabaklar, tırmanmak için küçük kayalar ve plastik tırmanma ekipmanları bulunmaktadır. Okul binasının sağ tarafında, yeşillik doğal bir alan bulunmaktadır. Binanın arka tarafında birkaç ağaç ve bitki bulunan küçük bir alan daha vardır. Ayrıca arka tarafta, salıncaklar, kaydıraklar, tırmanma ve denge çubukları içeren oyun ekipmanları bulunmaktadır. Arka kısım diğer kısımlardan farklı olarak çit yerine duvarla çevrilidir. Bu alanda, çocukların sanat eserlerini sergiledikleri ve aktif olarak kullandıkları kısa duvar bulunmaktadır. Ayrıca bu kısımda, duvara tutturulmuş ahşap bir tırmanma duvarı da bulunmaktadir.

Üçüncü anaokulu, şehrin kalabalık bir kesiminde yer alan, etrafinda çok sayıda binaların yer aldığı çok katlı bir binaya sahip doğal olmayan bir anaokuludur. Okul bahçesi, çitlerle çevrili olup, etrafta peyzaj amaçlı az sayıda çiçek, ufak bir çim alan ve birkaç küçük ağaç bulunmaktadır. Ayrıca, okulun girişinde bir çizgi film karakterinin oldukça büyük boyutta bir heykeli bulunmaktadır. Okulun açık hava oyun alanı binanın sağ tarafında kalan küçük ve dar bir alandır. Zemin kaplaması herhangi bir bitkinin veya ağacın yetişemeyeceği yapay çimden oluşmuştur. Bu alanda salıncak, kaydırak ve bir adet oyun evi ile sınırlı plastik oyun malzemeleri bulunmaktadır.

Dördüncü anaokulu ise çocuklara çok kısıtlı bir oyun alanı sunan, nispeten küçük ve doğal malzemelerin yok denecek kadar az bulunduğu doğal olmayan bir okuldur. Bahçe zemini çimen yeşili suni bir döşeme ile kaplıdır. Suni çim ile kaplanmış alan ile okul çevresi arasındaki saksılara dikili ince çalıların ve çiçeklerin bulunduğu küçük bir alan bulunmaktadır. Çitlerin köşesinde okul bahçesine dışardan giriş-çıkışın yapılabileceği metal bir kapı bulunmaktadır. Oyun alanının sınırları metal çitlerle belirlenmiştir. Okulu çevreleyen çitlerin hemen arkasında ise kaldırımı olan bir sokak bulunmaktadır.

\section{Örneklem/Çalışma Grubu}

Çalışmanın temel örneklemi okul öncesi eğitim kurumlarına devam eden 60-66 aylık 105 çocuktan oluşmaktadır. Bu çocuklar, çalışmanın kapsamı doğrultusunda belirlenen kriterler göz önünde bulundurularak dört farklı kurumdan rastgele örnekleme yöntemi kullanılarak seçilmiştir. Çalışmanın alt örneklemini ise temel örneklem grubundan rastgele örnekleme yöntemi kullanılarak seçilen 20 çocuk oluşturmuştur. Örneklem grubundaki çocukların demografik bilgileri Tablo 1'de belirtilmiştir. 
Y1lmaz ve Olgan

Tablo 1

Kat1lımc1ların Demografik Bilgileri

\begin{tabular}{llllll}
\hline $\begin{array}{l}\text { Toplam } \\
\text { Katılımcı Sayısı }\end{array}$ & Yaş (ay) & Cinsiyet & \multicolumn{2}{c}{ Okul Türü } \\
\cline { 3 - 6 } & & Kız & Erkek & Doğal & $\begin{array}{l}\text { Doğal } \\
\text { olmayan }\end{array}$ \\
\hline 105 (Temel örneklem) & $60-66$ & 59 & 46 & 50 & 55 \\
20 (Alt örneklem) & $60-66$ & 10 & 10 & 10 & 10 \\
\hline
\end{tabular}

\section{Veri Toplama Araçları}

Bu çalışmada, 'Çocuklar için Biyofili Ölçeği' kullanılmıştır. Çocuklar için geliştirilen biyofili ölçeği içerik olarak 22 madden oluşmakta ve görüşme soruları içermektedir. Ölçek maddelerinin yarısı biyofilik maddeler olarak nitelendirilirken, diğer yarısı ise biyofobik maddelerden oluşmaktadır. Figür 1'de biyofilik ve biyofobik madde örnekleri belirtilmiştir. Rice ve Torquati (2013) tarafından geliştirilen bu ölçeğin Cronbach alfa değeri .63 olup, ölçek yeterli güvenilirliğe sahiptir. Bu araştırma kapsamında, okul öncesi eğitim alanında uzman üç araştırmacı iki yönlü çeviri yöntemini kullanarak, ölçeğin Türkçe'ye adaptasyonunu gerçekleştirmiştir. Öncelikle ölçek maddeleri uzmanlar tarafından Türkçe'ye çevrilmiştir. Daha sonra, aynı ölçek maddeleri yine uzmanlar tarafindan Türkçe'den tekrar İngilizce'ye çevrilmiştir. Bu süreçte uzmanlar ayrıca ölçek maddelerinin kültürel uygunluğunu da göz önünde bulundurmuştur. Sonuç olarak, üç araştırmacı da ölçek maddelerinden yalnızca birinin yeniden düzenlenmesi konusunda hemfikir olmuştur. Türkçe'ye adapte edilen ölçeğin Cronbach alfa iç tutarlık katsayısı .68 olarak hesaplanmış olup, ölçek yeterli güvenilirliğe sahiptir.

Çalışmanın geçerliliği kapsamında ayrıca, ölçme aracının görünüş geçerliliği ile ilgili olarak okul öncesi eğitim alanında üç araştrmacıdan uzman görüşü alınmıştır. Araştırmacılar, ölçek maddelerinin her birinin anlaşılırlığını ve içerik olarak uygunluğunu doğrulamıştır. Ayrıca, altı çocukla yapılan pilot çalışma sonucunda, çocuklardan üçünün ölçek uygulamasını oyun olarak algılayıp, ölçeğin kendilerine tekrar uygulanmasını istedikleri görülmüştür. Ölçeğin bu üç çocuğa ikinci kez uygulanması sonucunda, çocukların ölçek maddelerine ikinci kez aynı yanıtları vermeleri, ölçek maddelerinin iyi bir görünüş geçerliliğine sahip olduğunu doğrulamıştır.

Pilot çalışma sürecince ayrıca, ölçek maddelerinin içerik olarak uygunluğu ve her bir ölçek maddesi için oluşturulan resimlerin ölçek maddeleri ile tutarlılı̆̆ çalışmanın veri toplama aracının güvenilirliğini artırmak amaçlanmıştır. Pilot çalışma sonucunda, ölçek maddelerinin her birinin açık ve anlaşılabilir olduğu ve ölçek maddelerinin her biri için geliştirilen resimlerin, ölçek maddelerini somutlaştırarak çocukların bu maddeleri daha iyi anlamalarını sağladığı tespit edilmiştir.

Rice ve Torquati (2013), ölçeğin kullanımında kukla ile uygulama yapmıştır. Orijinal uygulamadan farklı olarak, mevcut çalışmada ölçek maddeleri okul öncesi eğitim uzmanlarının görüşü alınarak, görsel biçimde tasarlanmış ve bir ressam tarafından çizimi yapılarak somutlaştırılmıştır. Bu somutlaştırma ile çocukların ölçeğe ilgilerinin arttırılması ve ölçek maddelerini çocukların daha iyi bir şekilde anlamlandırabilmesi amaçlanmıştır. 


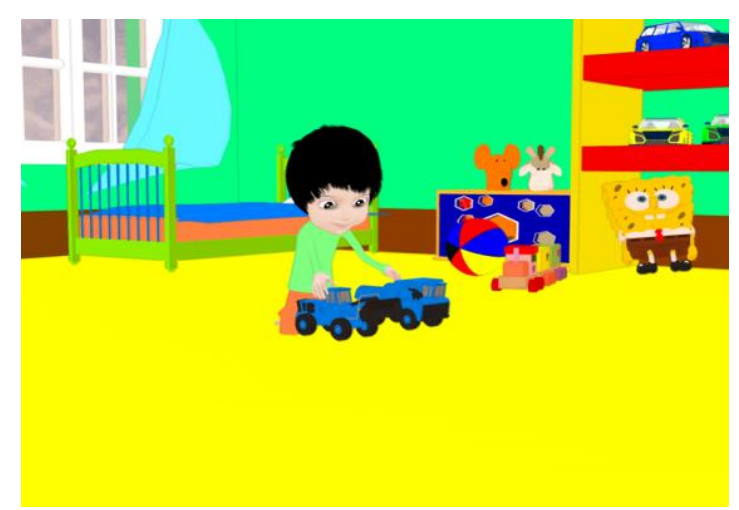

Biyofobik madde

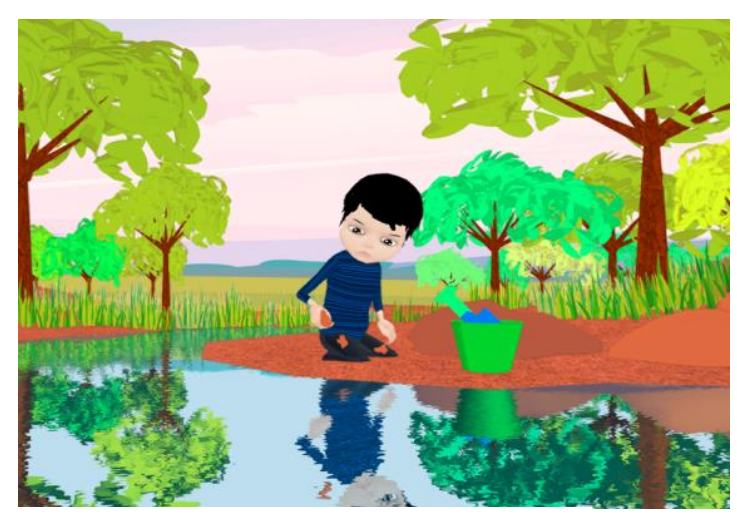

Biyofilik madde

Şekil 1. Çocuklar İçin Biyofili Ölçeği’nden Biyofilik ve Biyofobik Madde Örneği

"Bu çocuk içerde oynamaktan hoşlanır (biyofobik). Bu çocuk dışarda oynamaktan hoşlanır (biyofilik)"

\section{Veri Toplama Yöntemleri}

Çalışma verilerinin toplanma süreci, her bir katılımcı çocuğun devam ettiği okul öncesi eğitim kurumunda, sessiz bir sınıfta, ölçüm aracının her bir çocuğa bireysel olarak uygulanması ile gerçekleşmiştir. 'Çocuklar için Biyofili Ölçeği' nin biyofilik ve biyofobik her bir maddesi, araştırmacılardan biri tarafından maddelerin görseli ile birlikte her bir çocuğa yüksek sesle okunmuştur. Araştırmacı, bunun ardından her bir çocuğa 'Sen hangi kız/erkek gibi yapardın?' şeklinde soru yönelterek, görsellerden birini seçmesini istemiş ve her bir çocuğa bu seçimi neden yaptığını sormuştur. Her bir uygulama yaklaşık 20 dakika sürmüş olup, veri toplama süresi toplamda yaklaşık olarak otuz beş saattir. Katılımcı çocukların yanıtları biyofilik maddeleri seçmeleri durumunda 1 puan olarak kodlanırken, biyofobik maddeleri seçmeleri durumunda 0 (sıfır) puan olarak kodlanmıştır.

\section{Verilerin Analizi}

Nicel veri analizi

Katılımcı çocukların biyofili puanları 'Çocuklar için Biyofili Ölçeği' kullanılarak elde edilen veriler doğrultusunda betimleyici ve yordayıcı analiz yöntemleri ile belirlenmiştir. $\mathrm{Bu}$ doğrultuda, doğal ve doğal olmayan okullara devam eden çocukların biyofili puanlarında istatistiksel olarak anlamlı bir fark olup olmadığını belirlemek amacıyla bağımsız gruplar için t-testi analizi kullanılmıştır. Benzer şekilde, cinsiyet değişkeninin de çocukların biyofili puanları üzerinde etkiye sahip olup olmadığı da bağımsız t-testi ile analiz edilmiştir. Okul türü ya da cinsiyet faktörünün katılımcıların biyofilileri üzerindeki etkisini araştırmadan önce, veri grubunun normallik varsayımının sınanmasında Kolmogorov-Smirnov testi ve veri setinin homojenliğini test etmek amacı ile de Levene istatistiği kullanılmıştır. Her iki durumda da Kolmogorov-Simirnov testleri sira ile $p=.276$ ve $p=.268$ olup, $p$ değeri .05 ten büyük olduğu için normal dağılım varsayımının sağlandığı görülmüştür. Ayrıca, istatistiksel olarak anlamlı değer, her iki durum için de sirasıyla $p=.07$ ve $p=.10$ olup, $p=.05$ den büyük olduğu için, varyansların homojenliğinin de sağlandığı belirlenmiştir.

\section{Nitel veri analizi}

Nitel veri analiz süreci başlangıcında, katılımcılarla yapılan birebir görüşme kayıtlanı araştırmacılar tarafindan yazılı doküman haline getirilmiş ve Creswell (2007)'in önerisi göz önünde bulundurularak, okul öncesi eğitimi alanında doktora derecesine sahip iki uzman tarafından analiz edilmiştir.

Verilerin analizi, ölçeğin uygulaması sırasında katılımcıların vermiş olduğu yanıtların ses kayıtları yazılı hale getirilmiş ve Creswell'in (2007) önerisi temel alınarak bağımsız bir şekilde gerçekleştirmiştir. Her iki araştırmacının, katılımcıların yanıtlarını biyofilik ve biyofobik olarak belirlemesinin ardından, çalışma bulgularının geçerliğini artırmak amacıyla her iki uzmanın bulguları, Miles ve Huberman (1994) tarafından önerilen formül (Güvenirlik: 
[Görüş birliği / (Görüş birliği + Görüş ayrıllı̆ğ) x 100] kullanılarak hesaplanmıştır. Sonuç olarak, uzmanlar arasında \%96 oranında örtüşme sağlanmış ve fikir birliğine varılmıştır.

\section{Bulgular}

Bu bölümde nicel ve nitel analiz yöntemleri kullanılarak elde edilen bulgulara yer verilmiştir.

\section{Nicel Bulgular}

$\mathrm{Bu}$ bölümde öncelikle nicel analiz sonuçları verilmiştir. Katılımcı 105 çocuğun biyofili puanlarının tanımlayıcı istatistikleri hesaplanmıştır. Hesaplamalar çocukların biyofili puanlarının her iki okul türünde de birbirlerine yakın ve oldukça yüksek olduğunu göstermektedir (Bkz: Tablo 2).

Tablo 2

Okul Türüne Göre Çocukların Biyofili Puanları

\begin{tabular}{cccccc}
\hline \multicolumn{7}{c}{ Tanımlayıcı İstatistik } \\
\hline $\begin{array}{c}\text { Biyofili } \\
\text { puanları }\end{array}$ & $\mathrm{N}$ & Ortalama & Alt sınır & Üst sınır & $\begin{array}{c}\text { Std. } \\
\text { Sapma }\end{array}$ \\
\hline Doğal & 50 & 8 & 2 & 11 & 1.87 \\
$\begin{array}{c}\text { Doğal } \\
\text { olmayan }\end{array}$ & 55 & 7.84 & 3 & 11 & 2.15 \\
Toplam & 105 & 7.9 & 2 & 11 & 2 \\
\hline
\end{tabular}

Biyofili puanlarının hesaplanmasının ardından, çocukların biyofililerinin kayıt oldukları okul türüne göre istatistiksel olarak anlamlı bir farklılık gösterip göstermediği bağımsız gruplar için t-testi kullanılarak analiz edilmiştir. Analiz sonuçları Tablo 3'te sunulmuştur.

Tablo 3

Çocukların Biyofili Puanlarının Okul Türüne Göre Bağımsız Gruplar İçin t-testi Bulguları

\begin{tabular}{|c|c|c|c|c|c|c|c|c|c|}
\hline \multicolumn{5}{|c|}{ Levene testi } & \multicolumn{5}{|c|}{ Bağımsız gruplar için t-testi } \\
\hline & & \multirow[t]{2}{*}{$\mathrm{F}$} & \multirow[t]{2}{*}{$\mathrm{t}$} & \multirow[t]{2}{*}{ df } & \multirow[t]{2}{*}{$p$} & \multirow[t]{2}{*}{$\begin{array}{l}\text { Ortalama } \\
\text { fark1 }\end{array}$} & \multirow{2}{*}{$\begin{array}{l}\text { Std. } \\
\text { hata } \\
\text { fark1 }\end{array}$} & \multicolumn{2}{|c|}{$\begin{array}{l}\% 95 \text { güven } \\
\text { aralığı }\end{array}$} \\
\hline & & & & & & & & $\begin{array}{l}\text { Alt } \\
\text { sinir }\end{array}$ & $\begin{array}{l}\text { Üst } \\
\text { sin11 }\end{array}$ \\
\hline $\begin{array}{l}\text { Toplam } \\
\text { biyofili } \\
\text { puanlar1 }\end{array}$ & $\begin{array}{l}\text { Eşit } \\
\text { varyans } \\
\text { varsayımı }\end{array}$ & .78 & .38 & 103 & .68 & .16 & .38 & .62 & .94 \\
\hline
\end{tabular}

Bağımsız gruplar için t-testi sonuçları varyansların homojenliği için yapılan Levene istatistiği sonuçları göz önüne alınarak yorumlanmıştır. Tablo 3'de de görüldüğü gibi, grupların varyansları eşit bulunmuştur $(\mathrm{F}=.78, p>.05)$. Varyans eşitliği gözönüne alınarak hesaplanan bağımsız gruplar için t-testi sonucuna göre, doğal olan okullara kayıtlı çocukların biyofili puanları $(\bar{X}=8, S S=1.87)$ ile doğal olmayan okullara kayıtlı çocukların biyofili puanları $(\overline{\mathrm{X}}=7.84, \mathrm{SS}=2.15)$ arasındaki ortalama puan farkı istatistiksel olarak anlamlı değildir $(t(103)=.41, p=.16, p>.05)$. Benzer şekilde, çocukların biyofili puanları cinsiyet faktörü göz önüne alınarak hesaplanmış ve ortalama değerleri erkekler ve kızlar için sırasıyla $\bar{X}=8.13$ ( $\mathrm{SS}=1.87)$ ve $\overline{\mathrm{X}}=7.76(\mathrm{SS}=2.15)$ olarak hesaplanmıştır (Bkz: Tablo 4). 
Tablo 4

Çocukların Cinsiyetine Göre Biyofili Puanları

\begin{tabular}{cccccc}
\hline \multicolumn{7}{c}{ Tanımlayıc İstatistik } \\
\hline $\begin{array}{c}\text { Biyofili } \\
\text { puanları }\end{array}$ & $\mathrm{N}$ & Ortalama & Alt sınır & Üst sınır & $\begin{array}{c}\text { Std. } \\
\text { Sapma }\end{array}$ \\
\hline Erkek & 59 & 8.13 & 2 & 11 & 1.87 \\
K1z & 46 & 7.76 & 3 & 11 & 2.15 \\
\hline Toplam & 105 & 7.95 & 2 & 11 & 2 \\
\hline
\end{tabular}

Çocukların biyofili puanlarının okul türüne göre hesaplanmasının ardından, onların biyofili puanlarının cinsiyet faktörüne göre istatistiksel olarak anlamlı bir fark gösterip göstermediği bağımsız gruplar için t-testi yapılarak analiz edilmiştir (Bkz: Tablo 5). Bağımsız gruplar için t-testi sonuçları, varyansların homojenliği için yapılan Levene test sonucuna göre yorumlanmıştır. Levene test sonucuna göre grupların varyansları eşit bulunmuştur ( $\mathrm{F}=1.28$, $p>.05)$. Varyans eşitliği varsayılarak hesaplanan bağımsız gruplar için t-testi sonucuna göre, erkek ve kız çocukların biyofili puanları arasındaki ortalama puan farkı istatistiksel olarak anlamlı bulunmamıştır $(t(103)=.94, p=.35, p>.05)$.

Tablo 5

Çocukların Biyofili Puanlarının Cinsiyete Göre t-testi Sonucu

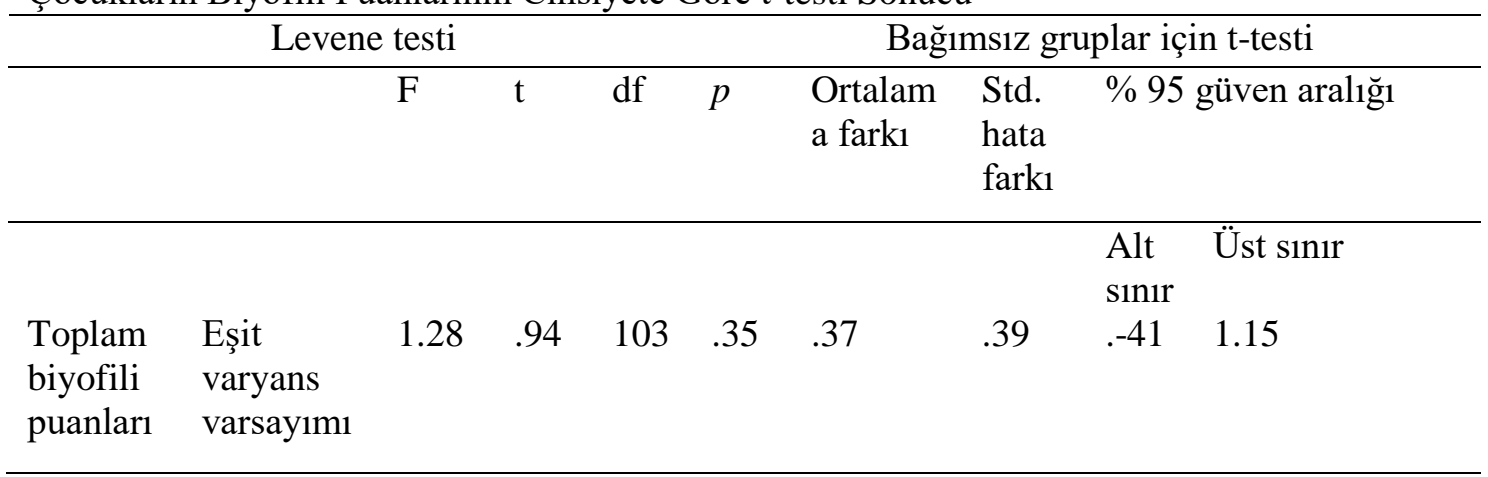

\section{Nitel Bulgular}

$\mathrm{Bu}$ bölümde araştırma verilerinin analiz sonuçları doğrultusunda, 20 çocuğun 22 ölçek maddesine vermiş olduğu biyofilik ya da biyofobik yanıtlarının sıklıkları ve nedenleri nitel araştırma yöntemleri kullanılarak analiz edilerek raporlanmıştır. Çocukların biyofili puanlarında hem cinsiyete hem okul türüne göre istatistiksel olarak anlamlı bir fark görülmediği için, okul türü ve cinsiyet ayrımı gözetmeksizin çocukların biyofili ölçeğindeki maddelere verdikleri yanıtlar bütünsel olarak analiz edilmiştir. Katılımcıların, her bir ölçek maddesi ile ilgili birden fazla açıklaması bulunabilmektedir. Cocukların tercihlerinin belirlenmesini sağlayan ölçek maddelerine bağlı olarak belirlenen kategoriler, çocukların biyofilik ya da biyofobik tercihlerinin sıklıkları, en sık rastlanan biyofilik ve biyofobik tercih nedenleri Tablo 6 da sunulmuştur. Çocukların diğer tercih nedenleri ise, her bir kategori için ayrı olarak ele alınmış olup, sıklıkları ile birlikte ilgili bölümlerde belirtilmiştir.

Tablo 6

Çocukların biyofilik ya da biyofobik tercihlerinin sıklıkları ve en sık rastlanan biyofilik ve biyofobik tercih nedenleri

\begin{tabular}{|c|c|c|}
\hline Kategoriler & $\begin{array}{l}\text { Biyofilik/Biyofobik } \\
\text { tercih s1kl1klar1 }\end{array}$ & Tercih nedenleri \\
\hline $\begin{array}{l}\text { Çocukların oyun } \\
\text { alanları ile ilgili } \\
\text { tercihleri }\end{array}$ & $\begin{array}{l}\text { Dişarda oynama: } 14 \\
\text { İçerde oynama: } 4 \\
\text { Her ikisi de: } 2\end{array}$ & $\begin{array}{l}\text { Biyofilik: Açık alanların çeşitli aktiviteler için } \\
\text { firsatlar sunması } \\
\text { Biyofobik: Fiziksel ve sosyal faktörlerin olumsuz }\end{array}$ \\
\hline
\end{tabular}




\begin{tabular}{|c|c|c|}
\hline & & etkisi \\
\hline $\begin{array}{l}\text { Çocukların toprağı } \\
\text { kazma tercihleri }\end{array}$ & $\begin{array}{l}\text { Tercih ederim: } 11 \\
\text { Tercih etmem: } 9\end{array}$ & $\begin{array}{l}\text { Biyofilik: Solucanların çok eğlenceli, tatlı ve güzel } \\
\text { olmaları } \\
\text { Biyofobik: Solucanların zarar verme ihtimali }\end{array}$ \\
\hline $\begin{array}{l}\text { Çocukların su } \\
\text { birikintisinde zıplama } \\
\text { tercihleri }\end{array}$ & $\begin{array}{l}\text { Tercih ederim: } 6 \\
\text { Tercih etmem: } 14\end{array}$ & $\begin{array}{l}\text { Biyofilik: Çok eğlenceli olması } \\
\text { Biyofobik: Kıyafelerinin kirlenmesi ve annelerinin bu } \\
\text { duruma kızma ihtimali }\end{array}$ \\
\hline $\begin{array}{l}\text { Çocukların kuşları } \\
\text { izleme tercihleri }\end{array}$ & $\begin{array}{l}\text { Tercih ederim: } 20 \\
\text { Tercih etmem: } 0\end{array}$ & $\begin{array}{l}\text { Biyofilik: Kuşların ötüşlerini dinlemekten keyif } \\
\text { almaları }\end{array}$ \\
\hline $\begin{array}{l}\text { Çocukların küçük } \\
\text { böcekleri yakalama ve } \\
\text { inceleme tercihleri }\end{array}$ & $\begin{array}{l}\text { Tercih ederim: } 11 \\
\text { Tercih etmem: } 9\end{array}$ & $\begin{array}{l}\text { Biyofilik: Küçük böceklerin zararsız olması ve bu } \\
\text { nedenle onlara dokunmaktan korkmamaları } \\
\text { Biyofobik: Küçük böceklerin kendilerine zarar verme } \\
\text { ve canlarını acıtma ihtimali }\end{array}$ \\
\hline $\begin{array}{l}\text { Çocukların kedi ve } \\
\text { köpekleri izleme } \\
\text { tercihleri }\end{array}$ & $\begin{array}{l}\text { Tercih ederim: } 16 \\
\text { Tercih etmem: } 4\end{array}$ & $\begin{array}{l}\text { Biyofilik: Kedi ve köpeklerle yapabilecekleri çeşitli } \\
\text { aktivite seçenekleri (kedi-köpek beslemek, top } \\
\text { yakalama oyunu oynamak vb.) } \\
\text { Biyofobik: Kedi ve köpeklerin kendilerine zarar } \\
\text { verebilme ihtimali }\end{array}$ \\
\hline $\begin{array}{l}\text { Çocukların su kenarında } \\
\text { oynama tercihleri }\end{array}$ & $\begin{array}{l}\text { Tercih ederim: } 16 \\
\text { Tercih etmem: } 4\end{array}$ & $\begin{array}{l}\text { Biyofilik: Su kenarında oynamanın çok eğlenceli } \\
\text { olması ve bu alanların çeşitli etkinlikler yapma firsatı } \\
\text { sunması } \\
\text { Biyofobik: Suya düşüp, sslanmaktan korkmaları }\end{array}$ \\
\hline $\begin{array}{l}\text { Çocukların doğal } \\
\text { maddelerle oynama } \\
\text { tercihleri }\end{array}$ & $\begin{array}{l}\text { Tercih ederim: } 17 \\
\text { Tercih etmem: } 3\end{array}$ & $\begin{array}{l}\text { Biyofilik: Doğal maddeleri kullanım amacının dışında } \\
\text { kullanabilme ihtimali } \\
\text { Biyofobik: Annelerinin kendilerine kızma ihtimali }\end{array}$ \\
\hline $\begin{array}{l}\text { Çocukların kuş seslerini } \\
\text { dinleme tercihleri }\end{array}$ & $\begin{array}{l}\text { Tercih ederim: } 18 \\
\text { Tercih etmem: } 2\end{array}$ & $\begin{array}{l}\text { Biyofilik: Kuş seslerinin çok güzel olması ve kuşların } \\
\text { çok güzel ötmeleri } \\
\text { Biyofobik: Kuşların seslerinin rahatsız edici olması }\end{array}$ \\
\hline $\begin{array}{l}\text { Çocukların gece } \\
\text { gökyüzünü izleme } \\
\text { tercihleri }\end{array}$ & $\begin{array}{l}\text { Tercih ederim: } 17 \\
\text { Tercih etmem: } 3\end{array}$ & $\begin{array}{l}\text { Biyofilik: Gökyüzü ile ilgili merak ettikleri birçok şey } \\
\text { olması } \\
\text { Biyofobik: Annelerinin izin vermemesi }\end{array}$ \\
\hline $\begin{array}{l}\text { Çocukların vahşi } \\
\text { hayvanlar hakkında } \\
\text { bilgi edinme tercihleri }\end{array}$ & $\begin{array}{l}\text { Tercih ederim: } 14 \\
\text { Tercih etmem: } 6\end{array}$ & $\begin{array}{l}\text { Biyofilik: Vahşi hayvanlarla ve onların yaşamlarıyla } \\
\text { ilgili merak ettikleri birçok şey olması } \\
\text { Biyofobik: Bu hayvanların onlara zarar verme } \\
\text { ihtimali }\end{array}$ \\
\hline
\end{tabular}

Çocukların Oyun Alanları İle Ilgili Tercihleri

Katılımcı çocuklara içerde ya da dişarda oynama seçenekleri sunularak, hangisini tercih edecekleri sorulduğunda, çocukların yarısından fazlası $(n=14)$ dışarda oynamayı tercih ederken, sadece dört çocuk içerde oynamayı tercih etmiştir. 20 çocuktan 2'si ise hem içerde hem de dişarda oynamayı tercih ettiklerini belirtmiştir.

Tercih nedenlerine bakıldığında, dışarda oynamayı tercih eden çocukların tamamı $(\mathrm{n}=14)$, dışarda yapabildikleri aktivitelerden bahsetmiştir. Bu aktiviteler parkta oyuncaklarla oynamak, koşmak, bisiklet sürmek, akülü araba kullanmak ve top oynamak şeklindedir. 14 
çocuktan 3'ü açık havada oynamayı çok sevdiğini ve bu ortamlarda temiz hava alma firsatı bulduğunu belirtmiştir. Çocuklardan bazıları (14 çocuktan 3'ü) ise, bisiklet sürmek, top oynamak vb. favori aktivitelerini içerde yaptıkları zaman annelerinin kızdığını belirterek, bu aktiviteleri rahatça yapabilmek için dişarda oynamayı tercih ettiklerini belirtmiştir. 14 çocuktan 2'si evde tek başına oynadıkları zaman canlarının sıkıldığını ve dışarda arkadaşlarıyla oynayabileceklerini belirtmiştir. 14 çocuktan yalnızca 1'i dışarıda ağaçların varlığından ve çimlerde oynayabilmenin rahatlığından bahsederek, açık alanda oynamak istemesinde doğal elementlerin varlığının etkili olduğunu belirtmiştir. Bazı çocukların ifadelerinden alıntılar aşağıda sunulmuştur:

"Dışarısı çok güzel ve havalı. Parkta oynamayı çok seviyorum. Özellikle, tahterevalliye binmeye ve salincakta sallanmaya bayllirm." (K10)

"Sallanmayı çok severim. Parkta koşarım, arkadaşlarımla oynarım." (K7)

"Dışarda top oynamak hoşuma gidiyor. Hem dişarda ağaçlar var. Çimlerin üzerinde oynamak da çok hoşuma gidiyor." (K4)

İçeride oynamayı tercih ettiklerini belirten çocukların $(n=4)$ ifadeleri incelendiğinde ise, içlerinden üç çocuk dışarda taşların, arabaların olması ya da havanın soğuk olması nedeniyle üşütebilme ihtimallerinin olması gibi fiziksel veya sosyal faktörlerin etkisinden dolayı dışarda rahat bir şekilde oynayamayacaklarını ve düşme ya da hasta olma ihtimallerinin olduğunu belirtmiştir. Dört çocuktan biri ise, oyuncaklarıyla oynamayı çok sevdiğini, ancak annesinin, kirlenme endişesinden dolayı, oyuncaklarını dışarı çıkarmasına izin vermediğini açıklamıştır. Çocukların açıklamalarından örnekler aşağıda yer almaktadır:

"Çünkü annem dı̧sarıya çıkma diyor. Oyuncaklarım pis olur diye dı̧̧arı çıkarmak istemiyorum. Evde oynamayı çok seviyorum." (K9)

"En sevdiğim oyuncaklarım evde. Oyuncaklarımla dışarda oynamayı pek sevmiyorum çünkü orda taşlar var. Taşların olduğ y yerde düşebiliyorum ve canım actyor. Mesela dışarda top oynarken düşebilirim." (K5)

Hem içeride hem dışarda oynamayı tercih eden çocukların $(n=2)$ görüşleri incelendiğindese, bu çocukların hem içerdeki oyuncaklarla hem de dış mekânlardaki oyuncaklarla oynamayı çok sevdikleri görülmüştür.

\section{Çocukların Toprağı Kazma Tercihleri}

Katılımcı çocuklara solucan bulmak için toprağı kazmayı tercih edip etmedikleri sorulduğunda, çocukların yarısından fazlası $(\mathrm{n}=11)$ bunu yapmayı tercih ettiğini belirtirken, diğer çocuklar (n=9) bu aktiviteden hoşlanmadıklarını belirtmiştir.

Topraktan solucan çıkarmayı tercih eden çocuklara bunun nedeni sorulduğunda, çocukların bir kısmı (11 çocuktan 4'ü) solucanları çok eğlenceli, tatlı ve güzel bulduğunu söylemiştir. Bazı çocuklar (11 çocuktan 3'ü) ise solucanlarla oyunlar oynamak istedikleri için toprağı kazıp solucan çıkarmayı sevdiklerini belirtmiştir. Örneğin;

"Solucanlardan korkmam, çok güzeller. Onlarla oynamak ve onları incitmemek isterim." (K8)

"Onlar çok tatl ve küçükler. Onlarla saklambaç oynarım. Onlar saklanır ben bulurum. Solucan yakalamayl severim. Solucan gel bana diyorum ve geliyorlar. Onlart tepsiye koyuyorum, evime getiriyorum ve besliyorum. Solucan yemi veriyorum, annemin marketinde var. Hep evimde tutuyorum. 'Solucan Vak Vak' adını veriyorum, çok seviyorum onları. Onlar büyüyünce bahçeye koyacağım sağllkl beslensinler ve susuz kalmasınlar diye." (K10)

Topraktan solucan çıkarmayı tercih eden çocuklardan bazıları (11 çocuktan 3'ü) solucanların onlara zarar vermediğini belirterek bu eylemi yapmayı tercih edebileceklerini belirtmiştir. Bazı çocuklar ise (11 çocuktan 3'ü), solucanların beslenme, bakım ve korunma gibi bir takım ihtiyaçlarını karşılamak için onları topraktan çıkarmayı tercih edebileceklerini 
belirtmiştir. Çocuklardan bir tanesi daha önce böyle bir deneyimi olmadığını, ancak bu şekilde toprağı kazarak solucanlar çıkarmaya istekli olduğunu belirtmiştir. Diğer bir çocuk ise bu aktiviteyi sevme nedenini, annesinin izin verdiği bir aktivite olduğunu belirterek açıklamıştır. Çocukların ifadelerinden bazıları şu şekildedir:

"Solucanların aç kalmasını istemem. Toprakta sıkışıp kalmasını da istemem, onları çıkarırım topraktan ve evime götürüp bakarım.” (K6)

"Solucanları çok severim. Topră̆ı kazarım, korkmam. Onlar bir şey yapmazlar. Zarar vermezler bana." (K17)

Toprağı kazarak solucan çıkarma eylemini yapmayı tercih etmeyen çocukların ifadelerine bakıldığında $(n=9)$ ise, bu çocukların neredeyse tamamı $(n=8)$ solucanların onları 1sırma, bacaklarına dolanma gibi hareketlerle kendilerine zarar verebileceği endişesi nedeniyle, bunu yapmayı tercih etmediklerini belirtmiştir. Bununla birlikte 9 çocuktan 1'i, solucanların çirkin olduğunu, 2'si solucanların pis olduğunu ve üzerini kirleteceğini, 1'i ise annesi solucanlardan korktuğu için kendisinin de korktuğunu belirtmiştir.

"Solucanlar insanın bacağına dolanırlar. Kuyrukları vardır, yılanlar gibilerdir, zarar verirler bize." (K3)

"Solucanlar üstüme çıkıyorlar. Onlara dokunmaktan korkarım. Üstümü kirletirler." (K13)

"Solucanlardan korkuyorum beni yerler diye. Dokunamam." (K18)

\section{Çocukları Su Birikintisinde Zıplama Tercihleri}

Çocuklara su birikintisinde zıplamayı tercih edip etmedikleri sorulduğunda, bazı çocuklar (20 çocuktan 6'sı) bunu yapmayı tercih edebileceğini belirtirken, çocukların yarısından fazlası (20 çocuktan 14'ü) ise bunu yapmayı tercih etmeyeceklerini belirtmiştir.

$\mathrm{Su}$ birikintisinde zıplamayı tercih eden çocuklara, bunun nedenleri sorulduğunda çocukların tamamı $(n=6)$, bunu yapmanın çok eğlenceli olduğunu belirtmiştir. Bu 6 çocuktan 3'ü, su birikintisinde zıplamanın onlara keyif vereceğini; ancak annelerinin onların bu eylemi yapmalarından hoşlanmayacağını, bu nedenle de eylemi gerçekleştirmeyeceklerini belirtmiştir. Örneğin bir çocuk: "Çamurlu suya girmek hoşuma giderdi, ama hiç girmedim. Annem kızar. Annem 'Giremezsin, hayır!' deyince, girmem” (K12). 6 çocuktan 1'i ise açıklamasında: "Annem kızabilir, 'Pis sularda oynamaman gerektiğini biliyorsun' der. Annem kızmasın diye oynamam, ama aslında kızmasaydı oynamak isterim." (K4) ifadesini kullanmıştır. 6 çocuktan 2'si ise, su birikintisinde zıplasalar dahi, annelerinin kızmayacağını, kıyafetlerini kirletseler bile sorun olmayacağını belirtmiştir. Bu çocuklardan bazılarının açıklamaları aşağıda yer almaktadir:

“Kıyafetlerim kirlenirse annem yıkar. Ona söylerim 'kızma anneciğim' derim. Anneciğim ben üstümü kirlettim ama çok eğlendim derim, kızmaz.” (K11)

"Su birikintilerini çok severim, atlarım. Annem kızmaz, üzerimi değiştirir.” (K17)

$\mathrm{Su}$ birikintisinde ziplamayı tercih etmeyen çocuklara $(\mathrm{n}=14)$ bunun nedenleri sorulduğunda ise, çocukların neredeyse tamamı $(n=13)$ kıyafelerinin kirleneceğini ve annelerinin buna kızacağını belirtmiştir. Su birikintisinde zıplamayı tercih etmeyen çocukların yarısı (14 çocuktan 7'si), anneleri kızmasa dahi kıyafetlerinin kirlenmesinden hoşlanmayacağı için bu eylemi yapmayacaklarını belirtmiştir. Bu çocuklardan bazılarının açıklamaları "Su birikintileri çok pistir. Kıyafetlerim ıslanır, sevmem. Annem de 'Kızım neden üstünü başını kirlettin, daha yeni aldım kıyafetlerini' der" (K10), "Annem ve babam izin vermez. Üstünü kirletme derler. İzin verseler bile ben istemem kıyafetlerim kirlenir diye" (K15) şeklinde olmuştur. Ancak bu 7 çocuktan 3'ü, şayet anneleri kızmasaydı, su birikintilerinde zıplamak isteyeceklerini belirtmiştir. Örneğin bir çocuk "Annem su birikintilerinin pis olduğunu ve bunlardan uzak durmam gerektiğini söyler. Annem izin verse oynardım. Üstüm çamur olurdu, ama hoşuma da giderdi” (K16) ifadesini kullanmıştır. 


\section{Çocukların Kuşları İzleme Tercihleri}

Çocuklara kuşları izlemeyi tercih edip etmeyecekleri sorulduğunda, çocukların tamamı $(n=20)$ bu eylemi yapmayı tercih edeceklerini belirtmiştir.

Katılımcı çocukların yarısı (20 çocuktan 10'u) kuşların ötüşlerini dinlemekten keyif aldığını belirterek, onları izlemeyi tercih ettiğini açıklamıştır. Çocuklardan bazıları $(n=6)$ ise açıklamalarında, kuşların tüylerinin, renklerinin güzel ve yumuşak oluşu gibi özelliklere yoğunlaşmıştır. Örneğin bir çocuğun açıklaması: "Çok güzel ve ince ses çıkarıyor kuşlar. Güzel, renkli tüyleri var. Bir de çok güzel ötüyorlar. Cik cik ötüyorum diyorlar.” (K11) şeklindedir.

Kuş seslerini dinlemekten keyif alan çocukların yarısına yakın bir kısmı (10 çocuktan 4'ü) kuşların beslenme ve barınma ihtiyacını karşılamayı istedikleri için, onları izlemekten hoşlandıklarını ve onları yakalamak istediklerini belirtmiştir. Örneğin çocuklardan biri:

"Kuşlar çok tatllar. Onları beslerim ve onlara su veririm. Kuşyemi veririm, renkleri çok güzel diye. Kuşlar bana 'Beni evde tutun, çok üşüyorum' diyorlar. Yem veriyorum, örtü veriyorum, su veriyorum ve ısınmalarını sağllyorum. Kuşların ötüşünü dinliyorum ve geri bırakıyorum onlarl doğaya." (K10)

Çocukların çok az bir kısmı (10 çocuktan 2'si), kuşları izlemelerinin nedeni olarak, onların nasıl uçtuklarını merak edip, anlamaya çalışmaları olarak belirtmişlerdir. 10 çocuktan yalnızca 1'i, kuşlar ona zarar vermeyeceği için, onları izlemeyi tercih ettiğini ifade etmiştir. Diğer bir çocuk ise diğerlerinden farklı olarak kuşları izlemeyi sevdiğini çünkü bu sayede ağaçları da izleyebildiğini belirtmiştir.

\section{Çocukların Küçük Böcekleri Yakalama ve İnceleme Tercihleri}

Katılımcılara küçük böcekleri yakalamayı ve incelemeyi tercih edip etmeyecekleri sorulduğunda, katılımcıların yarısından fazlasının (20 çocuktan 11'i) bunu yapmayı tercih edeceğini ve bir kısmının (20 çocuktan 9'u) ise bunu tercih etmeyeceği görülmüştür.

Küçük böcekleri yakalamayı ve incelemeyi tercih eden çocukların büyük bir kısmı (11 çocuktan 8'i), onların zararsız olduğunu belirtmiş ve bu nedenle onlara dokunmaktan korkmadıklarını ifade etmiştir. Bu çocukların yarısından fazlası (11 çocuktan 6'sı) ise, küçük böceklere karşı olumlu tepki vermelerine rağmen, bazı küçük böceklerin kendilerine zarar verebileceğini, ellerini ısırabileceğini ve canlarını acıtabileceğini belirtmiştir.

"Küçük böcekleri severim ama kelebeklere dokunamıyorum hemen kaçıyorlar. Arı ve sinekler uçup gitmezse dokunabilirim. Arıdan biraz korkarım iğnesi var onun. Sinekten korkmam o zararsiz." (K2)

"Çok seviyorum arl, kelebek, böcek ve karıncalarl. Onlar bize bir şey yapmazlar, onlara dokunmaktan da korkmam." (K12)

Çocuklardan bazıları (11 çocuktan 4'ü) bazı küçük böceklerin rengârenk kanatları olduğunu ve çok güzel göründüklerini belirterek, bu canlıların fiziksel özelliklerine odaklanmıştır. 11 çocuktan 1'i, annesi izin verdiği takdirde küçük böceklere dokunmaktan korkmayacağını ve onlarla oynayacağını belirtmiştir.

"Sinekler benden korkar kaçarlar. Arlları sevmem, beni sokarlar. Kelebekler daha güzeller, rengârenk kanatları var.” (K7)

Katılımcılardan küçük böcekleri yakalamayı ve incelemeyi tercih etmeyenlerin tamamı ise $(\mathrm{n}=9)$ bu tercihlerinin nedeni olarak, bu böceklerin kendilerine zarar verebileceğini, canlarını acıtabileceğini belirtmişlerdir. Bu çocukların tamamına yakını (9 çocuktan 8'i) kelebek ve sinek gibi kendilerine zarar vermeyeceğini düşündükleri böcekleri sevdiklerini belirtmiştir. 
"Sinekten korkuyorum, uçuyor, kaşındırıyor, kaşıyınca da acıyor, ısırdı bir kez ayağımı. Kelebekten korkmam severim o usirmaz." (K4)

"Küçük böcekler beni sokarlar ve rahatslz ederler. Kelebeği severim ama onlar da beni çok seviyor. Beni sevdikleri için elime konuyorlar." (K9)

\section{Çocukların Kedi ve Köpekleri İzleme Tercihleri}

Çocuklara kedi ve köpekleri izlemeyi tercih edip etmeyecekleri sorulduğunda, büyük çoğunluğunun ( $\mathrm{n}=16)$ bunu yapmaktan hoşlandığı ve az bir kısmının $(\mathrm{n}=4)$ ise bundan hoşlanmadığı görülmüştür.

Çocuklara kedi ve köpekleri izlemeyi neden tercih ettikleri sorulduğunda, onların büyük bir kısmı (16 çocuktan 12'si), bu hayvanlarla yapabilecekleri çeşitli aktivitelerden (kedi-köpek beslemek, top yakalama oyunu oynamak vb.) bahsetmiştir. Bu çocukların yarısından fazlası ise (16 çocuktan 11'i), kedi ve köpeklerin dış görünüşlerinin tatlı olduğunu, yumuşacık tüylere sahip oldukları için onları sevmek istediklerini ifade etmiştir. Çocukların çok az bir kısmı (16 çocuktan 2'si) ise kedi ve köpeklerin kendilerine zarar vermemesinden dolayı onları sevdiklerini belirtmiştir.

"Onlar bana zarar vermedikleri için onları severim. Onlarla oyun oynarım, top yakalamaca gibi." (K7)

"Onları elime almayı çok seviyorum. Beni ısırmıyorlar. Onlarla yakalamaca oynarım. Ben kovalarım ve yakalamaya çalışıım onları. Onları beslemeyi de severim, mama veririm." (K9)

"Kedi köpekleri çok severim ve oynarım onlarla, beslerim onları. Köpeklere kemik, kedilere süt veririm." (K17)

Kedi ve köpekleri izlemeyi tercih etmeyen dört çocuk ise, bu hayvanların kendilerine zarar verebilme ihtimali olduğunu belirtmiştir. Bu çocukların yarısı (4 çocuktan 2'si), bu hayvanları izlememe nedeni olarak annelerinin kendilerine kızabilme ihtimalini belirtmiştir. $\mathrm{Bu}$ çocuklardan bir kısmının açıklaması aşağıda görülebilir:

"Beni istrurlar köpekler, kediler de beni tırmalar." (K16)

"Kedi ve köpeklerin tırmiklart var, beni tırmalayabilirler. Annem de onlart izlememe ve onlara dokunmama izin vermez." (K20)

\section{Çocukların Su Kenarında Oynama Tercihleri}

Çocuklara dere ve göl kenarlarında oynamayı tercih edip etmeyecekleri sorulduğunda, çocukların çok büyük bir kısmı (20 çocuktan 16'sı) bu alanlarda oynamayı tercih ettiğini belirtirken, az sayıda çocuk (20 çocuktan 4'ü) bu eylemi yapmayı tercih etmediğini açıklamıştır. Bu çocukların çok büyük bir kısmı (16 çocuktan 13'ü) dere ve göl kenarında oynamayı tercih etmelerinin nedeni olarak, bu aktivitenin çok eğlenceli olduğunu ve bu alanlarda gemi yüzdürmek, su savaşı yapmak, suya taş atmak ve çiçekleri sulamak gibi birçok etkinliği yapabileceklerini belirtmiştir.

Örneğin katılımcılardan biri tercih etme nedenini; "Çünkü kâğıttan gemiyle oynamay1 çok seviyorum. Annem yardım ediyor gemiyi yaparken. Çok eğleniyorum" (K8) şeklinde açıklamıştır. Bir diğer çocuk ise, "Kürek ve kova ile oynamayı severim. Gemimi suya batırırım ve boşaltırım, su gelirse içine. Suyu çok severim. Kovamı suyla doldururum ve çimen ve otları koyarım içine ve yemek yaparım" (K10). Bu çocukların bazıları (16 çocuktan 3'ü), bu alanlarda direk suya girip üstlerini sslatacaklarını ve bundan keyif alacaklarını belirtmiştir. 16 çocuktan 3'ü ise dere veya göl kenarında bir deneyimleri olmadığını, ancak böyle bir deneyim yaşamaktan hoşlanacaklarını belirtmiştir.

Dere veya göl kenarında oynamayı tercih etmeyen çocukların açıklamaları incelendiğinde ise, 4 çocuğun tamamı da suya düşüp, sslanmaktan korktuklarını belirtmiştir. $\mathrm{Bu} 4$ çocuktan 3'ü, bu gibi alanlarda 1slandıkları takdirde annelerinin kendilerine kızacă̆ını belirtmiştir. Aynı zamanda bu çocuklardan biri, suda karşılaşabilecekleri tehlikeli 
hayvanlardan korktuğunu belirtirken, diğer bir çocuk ise suyun soğuk olmasından tedirgin olabileceğini ifade etmiştir. Çocukların açıklamalarından alıntılar aşağıdadır:

“Çünkü su buz gibi, soğuk olmasa severdim. Köpek balı̆̆l olur diye de korkarım.” (K7)

"Düşerim diye. Balıklar bana su slçratırlar ve rahatsız olurum, annem de kızar üstümü uslatırsam." (K9)

“Üstüm islanır. Sirllsılkam olurum. Annem kızar.” (K14)

\section{Çocukların Doğal Maddelerle Oynama Tercihleri}

Katılımcılara ağaç dalları, yapraklar ve kozalaklarla oynamayı tercih edip etmeyecekleri sorulduğunda, çocukların büyük bir kısmı $(n=17)$ ağaç dalları, yapraklar ve kozalaklar ile oynamayı tercih edeceğini belirtirken, bazı çocuklar ise $(n=3)$ bu etkinliği yapmayı tercih etmeyeceklerini belirtmiştir.

$\mathrm{Bu} 17$ çocuğun 16'sı ağaç dalları, yapraklar ve kozalaklar ile oynamayı tercih etmelerinin nedeni bu malzemeleri kullanım amacının dışında kullanmakla ilgilidir. Örneğin bir çocuğun açıklaması "Çünkü onlarla yemek yapabilirim. Tencerenin içene koyabilirim. Ateş yakarım çakmakla. Uçak, kanat yaparım ve oynarım. Uçağın kuyruğunu yaparım bu malzemelerle" (K12) şeklindedir. Başka bir çocuk ise "Davul keman gibi aletler yaparım dal ve kozalaklardan. Davul kullanmayı çok seviyorum güzel müzikler çıkarırım" (K10) açıklamasını yapmıştır.

Doğal malzemelerle oynamayı tercih eden çocuklardan yalnızca biri ise deneyim eksikliğinin onda bu tür malzemelerle oyun oynama isteği uyandırdığını belirtmiştir: "Bu malzemelerle hiç oynamadım daha önce, ama oynamak isterim. Yaprakları yelpaze gibi kullanırdım." (K1). Bu 17 çocuktan 1'i diğer nedenlere ek olarak, aslında bahsedilen doğal maddelerle oynamayı tercih edeceklerini, ancak annesi izin vermediği için bu gibi maddelerle oynayamadığını belirtmiştir.

Ağaç dalları, yapraklar ve kozalaklarla oynamayı tercih etmeyen 3 çocuktan 2'si neden olarak annelerinin kızacağını belirtmiştir. Bu 3 çocuktan 1'i ise, bu malzemelerin arasından tehlikeli ve kendisine zarar verebilecek bir böceğin çıkabileceğini belirtmiştir.

“A ‘̆aç dallarını sevmem, içinden örümcek çıkabilir. Örümcek olmasa oynamak isterdim.” (K5)

“Annem 'Bu gibi malzemelere dokunma, sadece oyuncaklarinla oyna.' diyor. Annem izin verse oynardım ama. Oyun kurardım yaprak ve kozalaklarla.” (K16)

\section{Çocukların Kuş Seslerini Dinleme Tercihleri}

Katılımcı çocuklara kuş seslerini dinlemeyi tercih edip etmeyecekleri sorulduğunda, çocukların çok büyük bir kısmının (20 çocuktan 18'i) kuş seslerini dinlemeyi tercih ettiği görülmüştür. Bunun nedenleri incelendiğinde, çocukların büyük bir kısmının (18 çocuktan 13’ü) kuşların seslerinin çok güzel olduğunu, çok güzel öttüklerini belirtmiştir.

Örneğin çocuklardan biri: "Çünkü çok güzel ve ince sesle ses çıkarıyor kuşlar. Güzel, renkli tüyleri var. Bir de çok güzel ötüyorlar. Cik cik ötüyorum diyorlar.” (K11) şeklinde açıklamıştır. Çocukların kuş seslerini dinlemeyi tercih etmelerinin farklı sebeplerine bakıldığında, çocuklar kuşların çok tatlı ve güzel göründüğünden (18 çocuktan 3'ü), onlara dokunmak ve onları sevmek istediklerinden $(n=2)$, onlara yiyecek ve bakım sağlamak istediklerinden $(\mathrm{n}=1)$ bahsetmiştir.

Bazı çocuklar ise (18 çocuktan 3'ü), anneleri ya da ailelerinden biri kuşları sevdiği için, oların sesini dinlemekten hoşlandıklarını açıklamıştır. Bu çocuklardan birinin söylemi "Cik cik diyorlar. Annem ve kardeşim de kuşları sevdiği için, ben de seviyorum" şeklinde olmuştur.

Katılımcı çocuklardan kuşların seslerini dinlemeyi tercih etmeyen az sayıda çocuk ise (20 çocuktan 2'si), bunun nedenini kuşların seslerinin rahatsız edici olduğunu belirtmiştir. Örneğin bir çocuk: "Kuşların ötüşleri başımı ağrıtıyor, kulaklarımı rahatsız ediyor" şeklinde bir açıklama yapmıştır. 


\section{Çocukların Gece Gökyüzü̈ü̈ İzleme Tercihleri}

Çocuklara geceleri ay ve yıldızları izlemeyi tercih edip etmeyecekleri sorulduğunda, 20 çocuktan 17'si geceleri ay ve yıldızları izlemeyi tercih edeceğini belirtirken, diğer çocuklar $(\mathrm{n}=3)$ ise bunun tam tersi bir ifade kullanmıştır.

Geceleri ay ve yıldızları izlemeyi tercih eden 17 katılımcının yarısından fazlas $(\mathrm{n}=10)$, bunun nedenin gökyüzü ile ilgili merak ettikleri birçok şey olduğunu belirtmiştir. Çocuklardan bazılarının ifadeleri aşağıda yer almaktadır:

"Çünkü ay ve gökyüzü ile ilgili merak ettiğim çok şey var. Bulutu da merak ediyorum. Geceleri neden bulut yok, merak ediyorum. Ay'ın şekli her gün aynı değil, bunun nedenini de merak ediyorum ve anlamaya çalışlyorum gökyüzüne bakarak." (K4)

"Ay dedenin evini görmek istiyorum. Ay dedenin ve yıldızların gökyüzüne nasıl çıttılarını merak ediyorum." (K6)

On yedi çocuktan bazısı ise ( $n=5)$, gökyüzünün çok güzel göründüğünü, gökyüzündeki ay ve yıldızların çok parlak olduğunu ve onları izlemeyi çok sevdiğini belirtmiştir. 17 çocuğun 2'si ise açıklamalarında annesi ile ilgili ifadelere yer vermiştir. Bu 2 çocuktan 1'i annesinin geceleri gökyüzünü izlemesine izin verdiğini belirtmiştir. Diğeri ise, geceleri gökyüzünü izlemeyi sevdiğini, ancak bunu yapmasına annesinin izin vermediğini belirtmiştir.

Geceleri ay ve yıldızları izlemeyi tercih etmeyen 3 çocuktan 2'si bunun nedenini annelerinin izin vermemesi ile açıklarken, geri kalan bir çocuk gökyüzünün kendisinin ilgisini çekmediğini ve gökyüzü ile ilgili merak ettiği bir şeyin olmadığını belirtmiştir. Örneğin bir çocuk "Onlara boşuna bakıyorum. Gerekli olmadığı zamanlar merak etmiyorum ay ve yıldızlarla ilgili bir şeyi. İlgimi çekmiyorlar" (K13) ifadesini kullanırken, diğer bir çocuk ise "İçerde oyuncaklarımla oynamayı çok seviyorum. Dışarısı soğuk oluyor diye annem kızıyor, izin vermiyor gökyüzünü izlememe" şeklinde bir açıklama yapmıştır.

\section{Çocukların Vahşi Hayvanlar Hakkında Bilgi Edinme Tercihleri}

Çocuklara vahşi hayvanlar hakkında bilgi edinmeyi isteyip istemeyecekleri sorulduğunda, 20 çocuktan 14'ü vahşi hayvanlar hakkında bilgi edinmek istediğini belirtirken, geri kalan 6 çocuk ise bunun tersi bir ifade kullanmıştır.

Bilgi edinmeyi tercih etme nedenleri sorulduğunda, 14 çocuğun tamamına yakını $(n=13)$ vahşi hayvanlar ve onların yaşamlarıyla ilgili merak ettikleri birçok şey olduğunu belirtmiştir. Örneğin bir çocuk, "Hoşuma gidiyor su aygırları, kaplanlar, dinazorlar. Timsah hakkında merak ettiğim şeyler var onların dişini merak ediyorum ve nasıl isırıp yediklerini. Kuyruğunu nasıl salladığını da merak ediyorum.” (K4) gibi bir açıklama yapmıştır. Diğer bir çocuk ise "Aslanların ve kaplanların pençelerini nasıl çıkardıklarını merak ediyorum. İnsanları ve başka hayvanları nasıl avlayabiliyorlar, nasıl hızlı koşabiliyorlar çok merak ediyorum." (K19)

Yukarıdaki açıklamalardan farklı olarak 14 çocuktan 1'i ise bu hayvanların onun hayvan dostları olduğunu ve onları çok sevdiğini belirtmiştir. $\mathrm{Bu}$ çocuk açıklamalarında "Onlar benim hayvan dostlarım. Onlar benim en iyi dostum. TV içine girmeyi ve onları sevmeyi hayal ediyorum." (K12) ifadesini kullanmıştır.

Vahşi hayvanlar hakkında bilgi edinmeyi istemeyen 6 çocuk ise bunun nedenlerini bu hayvanların onlara zarar verebileceğini $(n=3)$, onlarla ilgili merak ettikleri şeyler olmadığını $(\mathrm{n}=2)$, bunların yerine çizgi film izlemek istediklerini $(\mathrm{n}=2)$ ve annelerinin bu tür bilgiler edinmelerine izin vermediğini $(n=2)$ belirtmişlerdir. Çocukların açıklamalardan bazıları aşağıda görülebilir:

"Sevmiyorum aslanları ve diğer vahşi hayvanları. Onlar benim parmă̆ımı ısırırlar. Yılanları atarlar üzerime. Tirmalarlar beni. Oyuncaklarımla oynamayı tercih ederdim.” (K9) 
"Hayvanat bahçesine zaten gittim. Oyuncaklarımla oynamayı daha çok seviyorum. Çizgi film izlemeyi daha çok seviyorum." (K20)

"Çünkü vahşi hayvanlar çok sinirlidirler. Onlar bizi yiyebilir. Etimizi koparabilirler." (K6)

\section{Tartışma}

$\mathrm{Bu}$ bölümde mevcut çalışmanın bulguları özetlenerek alan yazındaki ilgili çalışmalarla karşılaştırılmıştır. Çalışmanın bulguları özetlenirken, çocukların doğa ile ilişkili her bir ölçek maddesine vermiş oldukları olumlu ve olumsuz tepkiler birlikte değerlendirilerek, bu doğrultuda yapılan çıkarımlara göre, özellikle en çok öne çıkan bulgular tartışılmıştır.

Mevcut çalışmanın nicel analiz bulgularına göre, çocuklar devam ettikleri okul türüne ve cinsiyetlerine göre farklılık göstermeksizin yüksek biyofili seviyelerine sahiptir. Diğer bir deyişle, çalışmaya katılan çocukların doğaya yakınlık seviyeleri oldukça yüksektir. Bu bulguyu destekler nitelikte Rice ve Torquati (2013) de çocukların biyofilisinin, kayıt oldukları okulun bahçesinin doğallık seviyesine bağlı olmadığını belirtmektedir. Benzer şekilde, Ahmetoğlu (2017) ve Lucas ve Dyment (2010) de çalışmalarında çocukların biyofili seviyelerinin cinsiyet faktörüne bağlı olmadığını, kız ve erkek çocukların doğanın sunduğu aktivite firsatlarını benzer şekilde tercih ettiklerini vurgulamaktadırlar. Diğer araştırmacılar da (Martensson ve diğerleri, 2014; Norodahl ve Einarsdottir, 2015) doğal alanların cinsiyete bağlı olmaksızın çocukların dikkatlerini çektiğini ve hem kız hem de erkek çocukların doğadaki maddeleri kullanma biçimlerinin özellikle küçük yaşlarda benzer olduğunu belirtmektedirler.

Mevcut çalışmanın bulgularına göre, çocukların doğa ile ilgili uyaranlara karşı olan hem olumlu hem olumsuz tepkilerinin şekillenmesinde annelerinin konu ile ilgili tutumları önemli rol oynamaktadır. Çocuklar doğa ile ilgili uyaranlarla etkileşim kurmak istedikleri halde (biyofilik tepki), annelerinin kendilerine kızma ihtimallerini dikkate alarak, doğa ile etkileşimlerini gerçekleştirmediklerini belirlenmiştir. Hatta bazı durumlarda çocuklar, annelerinin verebileceği tepkiler nedeniyle, doğa ile ilgili uyaranlara olumsuz tepki (biyofobik) vermektedirler. Bu durum sosyo-kültürel faktörlerin çocukların tercihleri üzerinde etkili olduğunu göz önüne sermektedir. İlgili alan yazındaki diğer çalışmalarda da annelerin çocuklarının doğa ile etkileşimlerini etkilediğini vurgulanmıştır. Birçok araştırmacı, annelerin çocuklarının açık alanlarda oynamasını kısıtladığını ve kısıtlama nedeni olarak da, çocuklarının güvenliği ile ilgili kaygılar taşıdıklarını vurgular (Brussoni ve diğerleri, 2012; Gundersen ve diğerleri, 2006; McNeish ve Roberts, 1995; Valentine ve McKendrick, 1997). Annelerin özellikle açık alanlarda çocuklarını korumaya yönelik aşırı koruyucu tutum sergilemelerinin nedeni olarak da, çocuklarının bu alanlarda karşılaşabilecekleri olası fiziksel yaralanmaları engellemek olduğu belirtilmiştir (Dal Santo, Goodman, Glik ve Jackson, 2004; Sandseter, 2009; Yılmaz, 2017). Örneğin, Yılmaz'ın (2017) çalışmasının bulgularına göre, anneler çocukların doğal alanlarda oynamalarını kısıtlama nedenleri olarak, bu alanlarda bitki örtüsünün çok sik olmasından veya vahşi hayvanlarla karşılaşma ihtimalinden kaynaklanabilecek olası fiziksel yaralanmalardan bahsetmiştir. Sandseter'e (2009) göre ise yetişkinlerin doğal alanlarda çocuklarına karşı aşırı koruyucu tutum sergilemelerinde kültürün etkisi büyüktür. Özellikle Türkiye'de aşırı koruyucu anne baba tutumu sergileyen ebeveynlerin, çocukların doğal alanlarda risk almalarını istememelerinde kültürün etkisi olabilir. Scott ve diğerleri (2015) ve Little (2010) de risk almaktan kaçınan kültürel zihniyetin çocukların açık alan etkinliklerinin olumlu etkilerinden faydalanmasını engellediğini vurgulamaktadır.

Çocukların doğa ile ilgili uyaranlara verdiği biyofilik ve biyofobik tepkilerin ortak nedenlerinden bir diğeri ise, çocukların doğa ile ilgili uyaranlara duydukları meraktır. Çocuklardaki merak duygusu, bazı durumlarda (örneğin, vahşi hayvanlarla ilgili ya da geceleri gökyüzüne bakmakla ilgili) onları biyofilik yanıtlar vermeye yönlendirirken, bazı durumlarda da biyofobik yanıtlar vermeye neden olduğu görülmüştür. Birçok araştırmacı (Dyment ve O'Connell, 2013; Lucas ve Dyment, 2010) da çocukların doğal alanları tercih etmelerinin nedeni olarak bu alanların onlarda merak uyandırmas1 ve serbest oyun firsatları sunmas1 olduğunu belirtmektedir. Araştırmacılar ayrıca çocukların doğal alan tercihlerinde özellikle 
bitki ve hayvanlara karşı meraklı ve ilgili olmalarının önemini belirtmektedir (Ertürk-Kara, Aydos ve Aydin, 2015; Uyar ve Genç, 2016).

Çalışmanın sonuçları değerlendirildiğinde, çok fazla öne çıkmamasına rağmen, açık alanlarda oynamayı tercih eden çocukların bu tercihlerinin bir diğer nedenin de bu alanlarda doğal materyallere kolaylıkla erişebilmeleri ve arkadaşları ile sosyalleşebilme imkânı bulabilmeleri olarak yorumlanabilir. Nedovic ve Morrissey (2013) de bu bulguyu destekler şekilde, çocukların doğal alanlarda oynamayı tercih etme nedenlerinin, bu alanlarda bulunan materyallerin çocuklar arasındaki sosyal etkileşimi artırması ile ilgili olabileceğini belirtmiştir. Açık alanlarda bulunan doğal maddeler (ağaç, çim, çiçek, su vb.) çocuklara çok zengin seçenekler sunabilmektedir. Benzer bulgular farklı araştırmacılar tarafından da belirtilmiştir. Örneğin, bazı araştırmacılar (Hart, 1979; Mahidin ve Maulan, 2012; Müderrisoğlu ve Gültekin, 2013; Tunstall ve diğerleri, 2004; White ve Stoecklin, 1998) bir alanda su bulunmasının, çocukların açık alan tercihlerinde etkili olduğunu belirtmektedir. Bu araştırmacılar, çocukların doğal çevrede oynama tercihlerinde bu alanlardaki çeşitli maddelerin yapılandırılmamış oyun firsatları için çok etkili uyarıcılar olduğunu vurgulamaktadırlar.

Mevcut çalışmanın bir diğer bulgusuna göre, çocukların doğa ile ilgili uyaranlara verdikleri biyofobik tepkilerin nedeninin doğal uyaranların kendilerine zarar verebilme ihtimali ile ilgili olduğu söylenebilir. Çocuklar özellikle doğadaki bazı canlıların (örn: arı ve sinek), onlara zarar verip, canlarını acitabilecekleri korkusu ile biyofobik yanıtlar verirken; doğada kendilerine zarar vermeyeceklerini düşündükleri canlılara (örn: kelebek, uğur böceği ve kuş) biyofilik tepkiler vermiştir. Bazı araştırmacılar da (Dyment, 2005; Scott, Boyd, Scott ve Colquhoun, 2015, Yılmaz, 2017) çocuklarla yaptıkları çalışmalarda, çocukların oynamayı tercih etmediği doğal alanların sık bitki örtüsüne sahip olduğunu, suyun ya da zehirli böceklerin yaratabileceği tehlikelerle dolu olabileceğini belirtmektedir.

Diğer taraftan, açık alanlar yerine bina içinde oynamayı tercih eden çocukların tercih nedenleri incelendiğinde ise, daha çok sosyo-kültürel ya da fiziksel faktörlerin etkili olduğu söylenebilir. Çalışmanın bulgularına göre, açık alanların çocukların oyun oynaması için uygun olmaması, fiziksel faktörler arasında sayılırken; çocukların hasta olmaları, kötü havada dışarı çıkmayı tercih etmemeleri ve annelerinin çocukların tercihleri üzerindeki etkileri sosyokültürel faktörler arasında sayılabilir. Van Andel (1990) çocuklarla yaptığı çalışmasında, çocukların trafiğgin yoğun olduğu alanlarda oynamayı tercih etmediğini, hatta bu alanlarda oynamaktan korktuğunu belirtmektedir. Veitch ve diğerleri (2006) de sosyal (yabanciların varlığı) ve fiziksel (trafik yoğunluğu) faktörlerin çocukların açık oyun alan tercihlerinde etkili olduğunu belirtmektedir. $\mathrm{Bu}$ çalışmanın bulgularından farklı olarak Kabadayı (2016) çocukların açık alanlarda oynamak yerine, bina içinde teknolojik araçlarla (örneğin, bilgisayar oyunları ve DVD) oynamayı tercih ettiklerini belirtmiştir.

Ayrıca, çocukların büyük bir bölümü dışarda oynamayı tercih etmektedirler. Çocuklar bunun nedenini çoğunlukla açık alanda rahatlıkla yapabilecekleri etkinliklerle bağdaştırmışlardır. Yapılan diğer çalışmalarda da benzer sonuçlara ulaşılarak su bulunduran doğal alanların macera oyunları oynamaları, doğal elementlere şekil vermeleri ve onları manipüle etme gibi çeşitli firsatlar sunması nedeniyle, çocukların bu alanlarda vakit geçirmeyi tercih ettikleri belirtilmiştir (Tunstall ve diğerleri, 2004; White ve Stoecklin, 1998). Dyment ve O'Connell (2013) ve Fjortoft'a göre (2004) de çocukların doğal açık alanlarda tercih ettikleri favori alanları kayalara tırmanabilecekleri, ağaç evler inşa edebilecekleri, yuvarlanıp kaymak gibi fiziksel aktiviteler yapabilecekleri ve saklambaç oynayabilecekleri alanlardır. Diğer araştırmacılar da çocukların düşük fiziksel yaralanma riski taşıdıkları ve büyük kaslarını rahatlıkla kullanabilecekleri doğal alanlarda oynamayı tercih ettiklerini belirtmiştir (Willenberg ve diğerleri, 2009).

Mevcut çalışmanın diğer bir bulgusuna göre, çocukların doğa ile ilgili uyaranlara verdikleri biyofilik tepkilerin öne çıkan bir diğer nedeni bu uyaranları dikkat çekici bulmalarıdır. Örneğin, çocuklar bazı doğal uyaranlarla çeşitli aktiviteler yapmayı (hayvanlarla oynamak, hayvanları beslemek vb.) tercih nedenleri arasında belirtmiştir. Çocukların doğal 
uyaranlara olan ilgileri ve buna bağlı olarak doğal açık alanlarda zaman geçirmeleri, bu alanlardaki canlılarla etkileşimde bulunmak ve çeşitli etkinlikler yapmak istemeleri literatürdeki birçok çalışmanın bulgularını destekler niteliktedir. Van Andel (1990) de çalışmasında çocukların ağaç ve açık alan bulunduran yeşil alanlarda zaman geçirmeyi tercih ettiklerini belirtirken, tercih nedenleri olarak bu alanların onların çeşitli aktiviteler yapabilmesi, birbirleri ile ve doğal maddelerle etkileşimde bulunabilmeleri için elverişi alanlar olduğunu belirtmiş̧ir. Çocukların doğal uyaranlara olan ilgileri, White ve Stoecklin'e göre ise (1998), doğada çok çeşitli açık uçlu materyallerin bulunması ve çocukların bunları etkinliklerinde istedikleri şekilde kullanabilme özgürlügüne sahip olmaları ile açıklanabilir. Ayrıca, doğal uyaranlar çocukların hayal gücü ve yaratıcılıklarını destekleyecek şekilde etkinlikler yapmalarına elverişli olduğu için de çocuklar bu uyaranlarla çeşitli aktiviteler yapmayı tercih nedeni olarak belirtmiş olabilirler (Moorre, 1986; White ve Stoecklin, 1998).

Daha önce yapılan araştırmaların bulgularının aksine, mevcut çalışma bulgularına göre, çalışmaya katılan çocukların vermiş olduğu biyofilik yanıtların, bu çocukların doğa deneyimlerinin yetersiz olması ile ilgili olduğu düşünülebilir. Çalışmaya katılan çocuklar, özellikle doğal uyaranlara verdikleri biyofilik yanıtlarında, benzer uyaranlarla (örneğin, kozalak ve ağaç dallarıyla oynamak, su kenarında oynamak ve toprağı kazmak) daha önce herhangi bir deneyimleri olmadığını, ancak kendilerine firsat sunulursa bu uyaranlarla oynamak istediklerini belirtmiştir. Benzer şekilde, Cheng ve Monroe (2012) da çocukların doğaya yakınlığı ve doğa deneyimleri arasında olumlu bir ilişki olduğunu belirtmiştir. Castonguay ve Jutras (2009) da çocukların kendilerine tanıdık gelen doğal alanları hiç bilmedikleri alanlara göre daha fazla tercih ettiklerini belirtmiştir.

\section{Sonuç ve Öneriler}

Mevcut çalışma bulguları çocukların biyofilisinin okul tipi ya da cinsiyete bağlı olmaksızın yüksek seviyede olduğunu göstermiştir. Çocukların biyofili seviyesinin yüksek olması, eğitim uygulamalarında avantaja dönüştürülebilir. $\mathrm{Bu}$ durumda, çocukların doğaya yakın olma eğilimini daha da artırmak ve uzun soluklu hale getirmek adına, özellikle ebeveynlere ve öğretmenlere büyük sorumluluklar düşmektedir. Öğretmenlerin okul bahçesinde ya da okul dışında çeşitli aktiviteler planlayarak, çocukların doğa ile etkileşimde bulunmalarını sağlamaları önerilebilir. Öğretmenin planlamış olduğu okul içi ve okul dışı etkinliklere ebeveynlerin katılımının desteklenmesi de, çocukların anne babaları ile birlikte farklı doğa deneyimleri kazanmaları açısından önem taşıyabilir.

Mevcut araştırmanın bulguları ile doğrudan bağlantılı olmasa da, özellikle öğretmen eğitimi programlarındaki çevre eğitimi ile ilgili derslerin sayısının artırılması ve okul öncesi öğretmen adaylarının nitelikli doğa etkinlikleri ile ilgili deneyim kazanmalarının sağlanması, çocukların doğaya yakınlıklarının arttırılmasında önemli role sahip olabilir. Ayrıca, alanda çalışan öğretmenlerin de seminerler veya hizmet içi eğitimlerle teorik olarak bilgilendirilmeleri ve uygulamaya yönelik deneyim kazanmaları, açık alan etkinliklerini eğitim programlarına etkili bir şekilde entegre etmelerini kolaylaştırabilir.

Çalışmanın bulguları, çocuklarının biyofilik ya da biyofobik tepkilerinde annelerin etkililiğini vurgulamaktadır. Annelerin özellikle, çocukların risk alabilecekleri aktivitelerde bulunmalarını tercih etmemeleri, bu etkinliklerin çocukların gelişim ve öğrenmelerine katkısını kısıtlayabilir. Annelerin konuyla ilgili bakış açısını değiştirmek için, çocukların açık alanlarda zorlu görevlerle başa çıkabilmeleri için cesaretlendirilmeleri gerektiğinin önemi, çocukların olası yaralanmaları ve bu yaralanmalara karşı alınabilecek güvenlik tedbirleri gibi konularda bilgilendirilmeleri yararlı olabilir.

Mevcut çalışma bulguları gözönünde bulundurularak, ileride yapılacak çalışmalar, annenin yaşı, eğitim seviyesi, dışarıda geçirdiği zaman, oturulan konut tipi, annenin çocukluğunun geçtiği çevre gibi demografik bilgilerin, çocukların biyofilik ya da biyofobik yanıtları üzerinde etkili olabileceği dikkate alınarak planlanabilir. Çocukların doğa ile etkileşimini sağlayacak bir diğer önemli yetişkin grubu ise öğretmenler olduğundan, öğretmenlerin doğa ile ilgili bilgi, tutum ve uygulamalarındaki farklılıkların, çocukların 
biyofilik ya da biyofobik tepkileri üzerindeki etkisi de ileride planlanacak araştırmaların konusu olabilir.

\section{Kaynaklar}

Ahmetoğlu, E. (2017). The contributions of familial and environmental factors to children's connection with nature and outdoor activities. Early Child Development and Care, 111.

Appleton, J. (1975). The experience of landscape. New York: John Wiley.

Appleton, J. (1996). The experinece of landscape. New York: Chichester.

Bekoff, M. ve Goodall, J. (2007). The emotional lives of animals: A leading scientist explores animal joy, sorrow, and empathy-and why they matter. Novato, CA: New World Library.

Brussoni, M., Olsen, L. L., Pike, I. ve Sleet, D. A. (2012). Risky play and children's safety: Balancing priorities for optimal child development. International Journal of Environmental Research and Public Health, 9(9), 3134-3148.

Castonguay, G. ve Jutras, S. (2009). Children's appreciation of outdoor places in a poor neighborhood. Journal of Environmental Psychology, 29(1), 101-109.

Chawla, L. (1999). Life paths into effective environmental action. The Journal of Environmental Education, 31(1), 15-26.

Chawla, L. (2006). Learning to love the natural world enough to protect it. Barn, 2, 57-78.

Chawla, L. (2007). Childhood experiences associated with care for the natural world: A theoretical framework for empirical results. Children Youth and Environments, 17(4), 144-170.

Cheng, J. C. H. ve Monroe, M. C. (2012). Connection to nature: Children's affective attitude toward nature. Environment and Behavior, 44(1), 31-49.

Clements, R. (2004). An investigation of the status of outdoor play. Contemporary Issues in Early Childhood, 5(1), 68-80.

Cook, D. M. ve Mineka, S. (1989). Observational conditioning of fear to fear-relevant verus fear-irrelevant stimuli in rhesus monkeys. Journal of Abnormal Psychology, 98, 448459.

Cook, D. M. ve Mineka, S. (1990). Selective associations in the observational conditioning of fear in rhesus monkeys. Journal of Experimental Psychology: Animal Behavior Processes, 16, 372-389.

Coss, R. G. ve Charles, E. P. (2004). The role of evolutionary hypotheses in psychological research: Instincts, affordances, and relic sex differences. Ecological Psychology, 16, 199-236.

Creswell, J. W. (2007). Qualitative inquiry and research design: Choosing among five traditions (2nd). Thousand Oaks, CA: Sage.

Dal Santo, J. A., Goodman, R. M., Glik, D. ve Jackson, K. (2004). Childhood unintentional injuries: Factors predicting injury risk among preschoolers. Journal of Pediatric Psychology, 29(4), 273-283.

Dubos, R. (1968). So human an animal. New York: Charles Scribners ve Sons.

Dyment, J. E. (2005). Gaining ground: The power and potential of green school grounds in the Toronto district school board. Toronto, Ontario: Evergreen.

Dyment, J. ve O'Connell, T. S. (2013). The impact of playground design on play choices and behaviors of pre-school children. Children's Geographies, 11(3), 263-280.

Engleson, D. C. ve Yockers, D. H. (1994). A guide to curriculum planning in environmental education. Wisconsin Department of Public Instruction.

Gardner, G. ve Stern, P. C. (2002). Environmental problems and human behavior (2 ${ }^{\text {nd }}$. ed.). Boston: Allyn \& Bacon.

Gundersen, V., Frivold, L. H., Myking, T. ve Oyen, B. H. (2006). Management of urban recreational woodlands: The case of Norway. Urban Forestry \& Urban Greening, $5(2), 73-82$. 
Iltis, H. H., Loucks, O. L. ve Andrews, P. (1970). Criteria for an optimum human environment. Science and Public Affairs-Bulletin of the Atomic Scientists, 26(1), 2-6.

Kabaday1, A. (2016). Teachers' metaphorical images on "counting jingle-it-playground" in children's plays of Turkish culture: Türk kültüründeki çocuk oyunlarında "saymacaebe-oyun alanı" üzerine öğretmen metaforları. Journal of Human Sciences, 13(2), 3252-3265.

Kahn, P. H. (1997). Developmental psychology and the biophilia hypothesis: Children's affiliation with nature. Developmental Review, 17(1), 1-61.

Kahn Jr, P. H. (2002). Children's affiliations with nature: Structure, development, and the problem of environmental generational amnesia. Children and nature: Psychological, sociocultural, and evolutionary investigations, 93-116.

Ertürk-Kara, G., Aydos, E. H. ve Aydin, Ö. (2015). Changing preschool children's attitudes into behavior towards selected environmental issues: An action research study. International Journal of Education in Mathematics, Science and Technology, 3(1), 46-63.

Kellert, S. R. (1993). The biological basis for human values of nature. S. Kellert ve E. O. Wilson (Yay. haz.). The biophilia hypothesis içinde (s. 42-69). Washington D. C.: Island Press.

Kellert, S. (1997). Kinship to mastery: Biophilia in human evolution and development. Washington, D. C.: Island Press.

Kellert, S. R. (2012). Building for life: Designing and understanding the human-nature connection. Island press.

Kellert, S. R. ve Wilson, E. O. (1995). The biophilia hypothesis. Island Press.

Little, H. (2010). Relationship between parents' beliefs and their responses to children's risktaking behavior during outdoor play. Journal of Early Childhood Research, 8(3), 315-330.

Louv, R. (2005, 2008). Last child in the woods: Saving our children from nature deficit disorder. Chapel Hill: Algonquin Books.

Lucas, A. J. ve Dyment, J. E. (2010). Where do children choose to play on the school ground? The influence of green design. Education 3-13, 38(2), 177-189.

Martensson, F., Jansson, M., Johansson, M., Raustorp, A., Kylin, M. ve Boldemann, C. (2014). The role of greenery for physical activity play at school grounds. Urban Forestry \& Urban Greening, 13(1), 103-113.

Mayer, F. S. ve Frantz, C. M. (2004). The connectedness to nature scale: A measure of individuals' feeling in community with nature. Journal of Environmental Psychology, 24(4), 503-515.

McNeish, D. ve Roberts, H. (1995). Playing it safe: Today's children at pIay. Barnardo's: Essex.

Miles, M. B. ve Huberman, A. M. (1994). An expanded sourcebook: qualitative data analysis. (2nd ed.). Thousand Oaks: SAGE Publications.

Mineka, S., Cook, M. D. ve Keir, R. (1984). Observational Conditioning of snake fear in rhesus monkeys. Journal of Abnormal Psychology, 93, 355-372.

Moore, R. C ve Marcus, C. C. (2008). Healthy planet, healthy children: Designing nature into the daily spaces of childhood. S. Kellert, J. Heerwagen ve M. Mador (Yay. haz.). Biophilic design: The theory, science, and practice of bringing buildings to life içinde (s. 153- 203). Hoboken, NJ: Wiley.

Nisbet, E. K., Zelenski, J. M. ve Murphy, S. A. (2009). The nature relatedness scale: Linking individuals' connection with nature to environmental concern and behavior. Environment and Behavior, 41(5), 715-740.

Norodahl, K. ve Einarsdottir, J. (2015). Children's views and preferences regarding their outdoor environment. Journal of Adventure Education \& Outdoor Learning, 15(2), 152-167. 
Orians, G. H. (1986). An ecological and evolutionary approach to landscape aesthetics. E. C. Penning-Rowsell ve D. Lowenthal (Yay. haz.). Landscape meanings and values içinde (s. 3-22). London: Allen and Unwin.

Orr, D. W. (1994). Earth in mind. Washington, DC: Island Press.

Rice, C. S. ve Torquati, J. C. (2013). Assessing connections between young children's affinity for nature and their experiences in natural outdoor settings in preschools. Children Youth and Environments, 23(2), 78-102.

Rivkin, M. S. (1995). The great outdoors: Restoring children's rights to play outside. Washington DC: National Association for the Education of Young Children.

Rosenow, N. (2008). Learning to love the earth and each other. Young Children, 63(1), 10-13.

Samways, M. J. (2007). Rescuing the extinction of experience. Biodiversity Conservation, 16, 1995-1997.

Sandseter, E. B. H. (2007). Categorising risky play-how can we identify risk- taking in children's play? European Early Childhood Education Research Journal, 15(2), 237252.

Sandseter, E. B. H. (2009). Affordances for risky play in preschool: The importance of features in the play environment. Early Childhood Education Journal, 36(5), 439446.

Schultz, P. W. (2000). Empathizing with nature: The effects of perspective taking on concern for environmental issues. Journal of Social Issues, 56, 391-406.

Scott, G. W., Boyd, M., Scott, L. ve Colquhoun, D. (2015). Barriers to biological fieldwork: What really prevents teaching out of doors? Journal of Biological Education, 49(2), 165-178.

Simaika, J. P. ve Samways, M. J. (2010). Biophilia as a universal ethic for conserving biodiversity. Conservation Biology, 24(3), 903-906.

Sobel, D. (2008). Children and nature: Design principles for educators. Portland ME: Stenhouse Publishers.

Stokes, D. L. (2006). Conservators of experience. Bioscience, 56, 6-7.

Thompson, J. E. ve Thompson, R. A. (2007). Natural connections: Children, nature, and social-emotional development. Exchange, 178, 46-49.

Tilbury, D. (1994). The critical learning years for environmental education. R. A. Wilson (Yay. haz.). Environmental education at the early childhood level içinde (s.11-13), Washington, DC: North American Association for Environmental Education.

Tunstall, S., Tapsell, S. ve House, M. (2004). Children's perceptions of river landscapes and play: What children's photographs reveal. Landscape Research, 29(2), 181-204.

Turner, W. R., Nakamura, T. ve Dinetti, M. (2004). Global urbanization and the separation of humans from nature. Bioscience, 54(6), 585-590.

Ulrich, R. S. (1993). Biophilia, biophobia, and natural landscapes. The Biophilia Hypothesis, 7, 73-137.

Uyar, R. Ö. ve Genç, M. M. Y. (2016). The ecocentric and anthropocentric attitudes of preschool children related to different environments. Okul öncesi dönem çocukların farklı çevre konularına yönelik ekosantrik ve antroposentrik tutumları. Journal of Human Sciences, 13(3), 4579-4594.

Valentine, G. ve McKendrck, J. (1997). Children's outdoor play: exploring parental concerns about children's safety and the changing nature of childhood. Geoforum, 28(2), 219235.

Wells, N. M. ve Lekies, K. S. (2006). Nature and the life course: Pathways from childhood nature experiences to adult environmentalism. Children Youth and Environments, $16(1), 1-24$.

White, R. (2004). Young children's relationship with nature: Its importance to children's development \& the earth's future. White Hutchinson Leisure \& Learning Group, 1-9. 
White, R. ve Stoecklin, V. (1998). Children's outdoor play \& learning environments: Returning to nature. Erişim adresi: https://www.whitehutchinson.com/children/ articles/outdoor.shtml

Willenberg, L. J., Ashbolt, R., Holland, D., Gibbs, L., MacDougall, C., Garrard, J. ve Waters, E. (2009). Increasing school playground physical activity: A mixed methods study combining environmental measures and children's perspectives. Journal of Science and Medicine in Sport, 13(2), 210-216.

Wilson, O. E. (1984). Biophilia. Cambridge, MA: Harvard University Press.

Wilson, E. O. (1993). Biophilia and the conservation ethic. S. Kellert ve E. O. Wilson (Yay. haz.). The biophilia hypothesis içinde (s. 31-44). Washington, DC: Island Press.

Y1lmaz, S. (2017). Investigation of 5-year-old preschool children's biophilia and children's and their mothers' outdoor setting preferences (Unpublished doctoral dissertation). Middle East Technical University, Ankara, Turkey.

\section{Extended Abstract \\ Introduction}

Biophilia is defined as a fundamental and genetically based human need and propensity, to affiliate with life and lifelike processes (Kahn, 1997). As a special interest of the current research, biophilia is defined as a basic and genetic foundation for individuals' positive responses or affinity towards nature (Wilson, 1993).

There are several theories that can be helpful to understand individuals' innate tendency to be close with any kind of natural stimuli. Many researchers (i.e., Appleton, 1975; Coss \& Charles, 2004; Orians, 1986; Wilson, 1984) assert that evolutionary origins of human beings impact their preferences for different features of a landscape. According to evolutionary perspective, human beings have an innate tendency to savanna-like landscapes including low bushes and groups of trees since they want to control the environment or to hide from the potential hazards (Appleton, 1975). Similarly, Wilson (1994) indicates that people seek good and plentiful landscapes that they can meet their needs to survive.

In addition to individuals' innate desire to be close with any kind of natural stimuli, human beings have also genetic predisposition to variety of adaptive responses, including negative responses (danger/avoidance) to a particular natural stimulus. These dangers or avoidances are associated with risk relevant natural stimulus, including animals (i.e., snakes and spiders) and situations (i.e., dark and height).

The development of biophilia or biophobia begins to occur in very young ages. Therefore, it is crucial to understand how biophilia or biophobia develops in young children. According to Thompson and Thompson (2007), young children have an innate tendency to investigate natural environments and willing to take initiatives for their own learnings there. This might be related to the opportunities and resources that such environments lead children to play and learn (Rivkin, 1995). Opposite to biophilia, biophobia could be culturally learned phenomenon, which individuals can learn how to react to fear relevant natural stimuli (Ulrich, 1993).

In the lights of aforementioned information, children need developmentally appropriate practices to investigate nature not only to benefit from the positive effects of nature, but also nurture their positive affiliation toward nature. Children also need such practices to protect themselves from the negative consequences of learned fears (Chawla, 2006; Sobel, 2008). Additionally, it is important for young children to have nature experiences to nurture their understanding of being an inseparable part of nature in the early years, since children's values, attitudes, and the fundamental orientations toward nature begin to be formed in these critical years (Kahn, 2002; Kellert, 1997).

With regard to the related research in the literature, the development of children's biophilia, as a basis for children's affinity for nature, has only recently been investigated by Rice and Torquati (2013). Considering the gap, the current research investigates preschool children's biophilia levels and explores what factors are affective in children's positive or 
negative responses to any kind of natural stimuli. Investigating children's biophilia could reveal their connection to or disconnection from the natural world (Schultz, Shriver, Tabanico \& Khazian, 2004). Schultz (2000) highlighted that understanding how children value and feel toward nature could provide insight about how they will respect and protect it in their future lives. Keeping this information in mind, this research investigates if 60-66 months children's biophilia significantly differs based on their school type and gender. This research also explores the reasons of children's positive and negative responses to natural stimuli.

\section{Method}

In this study, both quantitative and qualitative research methods were used to measure 60-66 months preschool children's biophilia, which is the degree to which they feel affinity toward nature. The participants of the research were 105 children who were randomly selected from four public preschools located in the same district of Ankara. The data gathering tool was "Children's Biophilia Measure" that contains 22 item. During the data collection process, each participant child was read the items one by one and shown two pictures for each item of the biophilia measure by the first researcher. The same scoring method as seen in the original study investigated by Rice and Torquati (2013) was used by the researchers of the current study. Children's responses for the biophilic items were assigned a value of 1 , and their responses for the biophobic items were assigned a zero. Children's levels of biophilia as well as whether or not school type and gender significantly affect children's biophilia were determined through quantitative research methods. The reasons of children's biophilic or biophobic responses for the items of the instrument were analyzed through qualitative research methods.

\section{Result}

Results showed that children regardless of their school type and gender have pretty high levels of biophilia. Results also revealed the reasons of children's bophilic or biophobic responses to natural stimuli. The most prominent reason expressed by children was related to culture, in particular the impact of mothers on their biophilic or biophobic responses to a natural stimulus. Children's curiosity to a natural stimulus, possible hazards of natural stimuli, lack of nature experiences, physical and socio-cultural factors, the existence of natural stimuli in particular environments, and opportunities for socializing were the other factors affecting children's biophilic or biophobic responses.

\section{Discussion}

Considering the results of the study, children's high levels of affinity toward nature can be sustained through the encouragements of teachers and parents. Teachers might be suggested to have sufficient information about how to use the outdoor environments in their early child care centers through well-developed teacher training and in-service trainings. Moreover, teachers might arrange field trips to natural settings to enrich children's learning and development by integrating outdoor activities to the curriculum.

Results of the study imply that the participating children might be coming from riskaverse culture. Therefore, it is important to inform both teachers and parents about the contributions of risk taking outdoors. It might be beneficial to inform parents and teachers about the importance of encouraging children to have risks in order to make them aware about their strengths and weaknesses. Moreover, these adults should be informed about safety principles and legislations about safety (Sandseter, 2007). 